Research, part of a Special Feature on Archetype Analysis in Sustainability Research

\title{
Sustainable rural renewal in China: archetypical patterns
}

\author{
$\underline{\text { Rongvu Wang }}^{1,2,3}$, Klaus Eisenack ${ }^{2}$ and Rong Tan ${ }^{1}$
}

\begin{abstract}
Against the backdrop of rural deprivation during the rapid urbanization of China since the end of the previous century, rural renewal has been regarded as a vital strategy for facilitating rural sustainability. Rural renewal in contemporary China involves activities that replan, consolidate, and redevelop the extant and idle rural construction land and then convert such land for alternative uses, including new rural settlement construction and rural industry development. However, given the regionally decentralized authoritarian (RDA) regime of China, i.e., a combination of political centralization and economic regional decentralization, the governance of rural renewal and its performance show great diversity. The objective of this study was to explore and elucidate the underlying patterns of sustainable rural renewal. Thus, from the social-ecological systems (SES) perspective, an archetype analysis was conducted based on primary data from 27 cases from the eastern, central, and western parts of China. In total, eight archetypical patterns were extracted, and the following three overarching implications were observed: (1) a governance system aligning with the attributes of rural land resources, the characteristics of actors, and the properties of interactions is essential for sustainable rural renewal; (2) decentralized or self-organized governance emerges to facilitate sustainable rural renewal; and (3) a long-term perspective of designing and enforcing rural renewal and distinctive land resource endowment contribute to rural sustainability. These findings may benefit China and other regions pursuing rural sustainability.
\end{abstract}

Key Words: archetypes; China; rural renewal; social-ecological systems; sustainability

\section{INTRODUCTION}

For decades, rural land use in China has been characterized as extensive and inefficient (Liu et al. 2014, Long 2014). Moreover, the rural living environment in China is poorly planned and of a low quality (Fang et al. 2007). In addition, the social wealth gap between rural and urban sectors is relatively large. In 2017, the income gap between urban and rural areas had reached 2.71:1 (NBSC 2018). The issues mentioned above pose severe challenges to rural sustainable development (Liu et al. 2010, König et al. 2014). Gradually, rural renewal has become a vital strategy in China in the pursuit of rural sustainability (Wang and Tan 2018). In 2005, the Chinese government advanced a proposal for rural renewal (16th CCCPC 2005). After more than a decade of practice, a "rural vitalization" strategy was proposed, depicting a more detailed blueprint for rural renewal in China, namely, the construction of a new countryside with thriving businesses, pleasant living environments, social etiquette and civility, effective governance and prosperity (19th CCCPC 2017). In fact, rural renewal also occurs worldwide, such as the Rural Development Policy (2014-2020) proposed by the European Union (EU 2014). However, this study focuses on land-related rural renewal in contemporary China. This type of rural renewal involves activities that replan, consolidate, and redevelop the extant and idle rural construction land and then convert such land for alternative uses, including new rural settlement construction and rural industry development.

In China, the governance system is characterized by a combination of political centralization and economic regional decentralization, namely, a regionally decentralized authoritarian (RDA) regime $(\mathrm{Xu}$ 2011). Under the RDA regime, local government officials are motivated to follow the central government's policies by making full use of the socioeconomic autonomy in their jurisdictions, while the central government controls the appointment and promotion of local government officials (Li 2018, Yang and Yan 2018). Because rural renewal is considered a national policy, local governments are motivated to directly lead, to encourage rural households to self-organize and to promote enterprises to participate in the projects. Consequently, different types of rural renewal exist in China. And more importantly, rural renewal performance exhibits even greater diversity. For instance, a successful type of rural renewal in one area may fail in other areas. Even in villages with similar conditions, the same renewal path can attain notable achievements in one village but perform poorly in other villages (Tang et al. 2014, 2016). Therefore, what contributes to sustainable rural renewal?

Numerous studies have investigated this question. The current literature on rural renewal in China not only reveals microlevel factors that might affect the performance of rural renewal, such as the endowments of rural households and villages, government functions, and the decision-making process, but also refers to macro-level factors, including fundamental institutions and the distinctive political, economic, social, and cultural contexts of China (Long et al. 2012, Li et al. 2014, Tang et al. 2015, Fang et al. 2016, Guo et al. 2017). From an international perspective, Osborne et al. (2004) note several challenges particular to rural renewal, including the spatial features of rural areas, the paucity of human capital in rural communities and a much lower resource level than that in urban communities. Furthermore, Osborne et al. (2006) emphasize the role of local voluntary and community sector infrastructure bodies in promoting and supporting rural renewal in the UK. Macken-Walsh and Curtin (2013) argue that the recent period of transition, historical experiences of socialism, and local variations determine the performance of rural renewal in postsocialist Lithuania. Rural renewal can be considered collective action. Drawn from a wide range of empirical studies investigating worldwide common pool resources (CPR) governance, such as forestry, pastures, fisheries, and irrigation systems, several critical determinants, i.e., design principles, of long-surviving collective action were delineated and illustrated

${ }^{1}$ School of Public Affairs, Zhejiang University, Hangzhou, China, ${ }^{2}$ Resource Economics Group, Humboldt-Universität zu Berlin, Germany, ${ }^{3}$ School of Public Affairs, Xiamen University, Xiamen, China 
(Ostrom 1990, 2005, 2009). From an Ostromian perspective, studies have explored the key to fostering and sustaining collective action targeting at rural development. Based on the role of common property organizations in rural development of a mountain area in Italy, Bassi and Carestiato (2016) suggest that local actors should self-organize and self-develop rules regarding the use of local resources and act collectively in the management of their own territory in harmony with local identity, culture, and natural resources. Jelsma et al. (2017) find that with strong collective institutions that involve shared income, regular meetings among members, and multiple relations among farmers, oil palm farmers can participate in supply chains on advantageous conditions and substantially increase productivity, thereby contributing to rural development of West Sumatra, Indonesia. Additionally, social capital and rural entrepreneurs are essential for collective action in sustainable rural tourism (Schmidt et al. 2016, Hwang and Stewart 2017).

However, to the best of our knowledge, these findings mainly stem from small-scale case studies, normally one to three cases; furthermore, the existing literature rarely explicitly reveals how the interplay or combination of various factors contributes to the performance differences in China's rural renewal. Hence, this study aims to fill this research gap. Particularly, the research question of this study is as follows: Which patterns lead to the emergence of sustainable rural renewal? In other words, how does the interplay or combination of diverse factors lead to sustainable rural renewal in China? To this end, based on primary data from 27 cases, we intend to conduct an archetype analysis (Oberlack and Eisenack 2018, Oberlack et al. 2019). These archetypes can serve as guidelines for improving sustainable rural renewal governance in China.

\section{CONCEPTS AND METHODS}

\section{Understanding sustainable rural renewal}

Sustainable rural renewal should achieve several sustainable development goals (SDGs) that are overarching for rural sustainability in contemporary China (Chen 2010, 2013, UN 2015). Against the backdrop of rural deprivation during the rapid urbanization of China since the end of the previous century, rural renewal refers to reversing the trend of rural degrowth and bridging the rural-urban development gap (Wang and Tan 2018). Basically, a better living environment should be provided in rural areas to improve sanitation and human well-being (Huang et al. 2011, Griggs et al. 2013, Xu et al. 2014). Thus, rural renewal is expected to establish modernized rural settlements that are compatible with the rural landscape and living convention. Further, rural incomes should be significantly increased, and rural vitality should be enhanced to reduce rural poverty and diminish the inequalities between rural and urban areas (Huang et al. 2011, Griggs et al. 2013, Xu et al. 2014). Therefore, rural renewal is expected to create more decent jobs and accelerate economic growth by consolidating and redeveloping the extant and idle rural construction land for secondary and tertiary industrial uses; moreover, rural renewal is expected to strengthen the agricultural sector by directly restoring and consolidating the idle rural construction land for modern agricultural use while reinforcing agricultural investment by using the revenue from rural construction land redevelopment for industrial use. Hence, in this study, we selected rural living environments, rural income, and rural vitality to serve as indicators of the performance of rural renewal, and this strategy is also consistent with the goals of the recently proposed national strategy for "rural vitalization" (19th CCCPC 2017). Although the ecological indicator is vital for sustainability, the decision makers and stakeholders in contemporary China focus more on narrowing the rural-urban development gap and fulfilling rural sustainability in the socioeconomic aspect. The ecological implications of rural renewal occur gradually and are difficult to identify within the scope of this paper. Hence, we define the concept of sustainable rural renewal from a socioeconomic perspective.

Rural renewal is considered a dynamic process in which actors, e.g., rural households, government, enterprise, etc. (A-variable), under certain governance, e.g., government-led, self-organized, enterprise-participated, etc., system (GS-variable) redevelop rural construction land resources (R-variable) for new rural settlement construction and rural industry development through certain interactions, i.e., scheme design, implementation, and revenue appropriation (I-variable), which leads to certain outcomes, i.e., rural living environment, rural income, and rural vitality (O-variable). Therefore, the SES framework developed by Ostrom (2009) was employed as the analytical framework for this study (Fig. 1). Each component of the framework was decomposed for the further study. In particular, the governance system component was divided from the perspectives of the network structures among actors as well as the operational and collective choice rules regulating actions, information, payoffs, etc. (Ostrom 2010). The division of the interaction component was consistent with the major and shared stages of rural renewal in contemporary China, i.e., scheme design, implementation, and revenue appropriation. Distinguishing the properties of each stage is useful for characterizing the interactions (Wang and Tan 2018). Thereby, each interaction variable was further decomposed in the specific analysis process, such as complexity, uncertainty, asset, and site specificity and the time horizon (Hagedorn 2008, Ostrom 2010). The extent of each interaction property was also categorized as being high or low level and long or short term. The outcome component was decomposed in accordance with the aforementioned goals of rural sustainability.

\section{A first-hand case-based archetype analysis}

Overview

Rural renewal can be conceived as a comprehensive interplay of SES. Thus, we build upon the SES framework but further distinguish diagnostic attributes, design attributes, and outcome attributes. Diagnostic attributes are considered contextual, i.e., various rural construction land resource endowments, actor characteristics, and interaction properties. Design attributes are features that can in principle be changed by the actors under consideration, i.e., a set of governance systems. Under specific contexts and designs, different types of (non)sustainable rural renewal can be represented by outcome attributes, e.g., adequately improved rural living environment, significantly increased rural income and enhanced rural vitality. A major goal of studies investigating sustainable rural renewal in China is to explicitly portray this interplay among the attributes and extract the underlying patterns based on substantial cases. Fortunately, a series of studies exploring other resources and environmental 
topics have already addressed a similar concern by using an archetype analysis (Oberlack and Eisenack 2014, Oberlack et al. 2016, Oberlack and Eisenack 2018).

Fig. 1. Social-ecological systems (SES) framework of rural renewal.

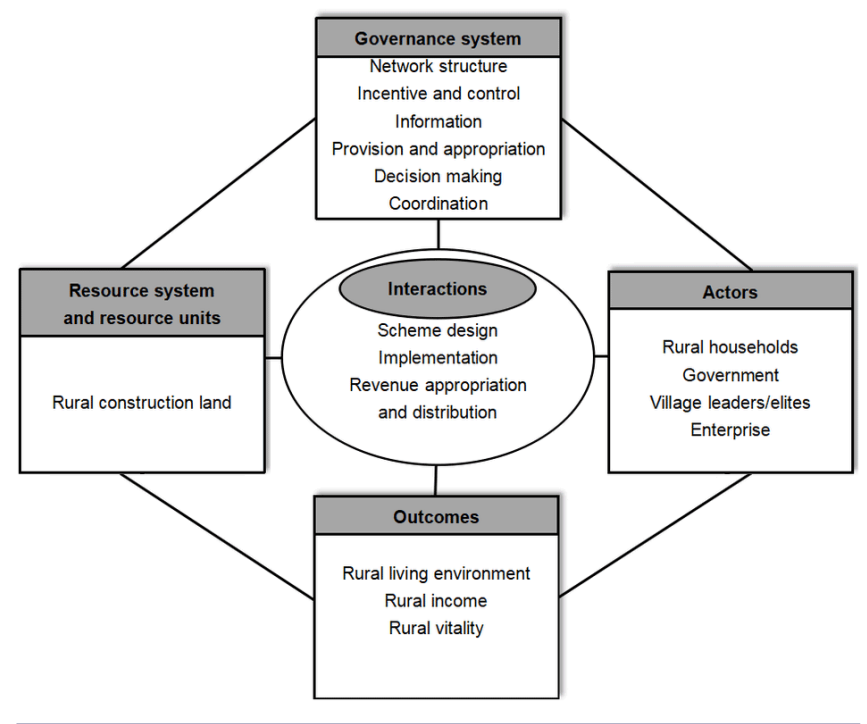

Archetypes are recurrent patterns of basic interplay in SES (Oberlack et al. 2019), and they function as building blocks of social-ecological interplay that recur in multiple cases. Put differently, not every case requires to be completely interpreted by a single archetype. One archetype can only partially cover a number of cases, and one case might be described by several archetypes (Eisenack et al. 2006). To perform such an analysis, the quality and design criteria of Eisenack et al. (2019) are used to orient this study. More quantitatively, archetypes can be defined from a set-theoretic perspective (Oberlack and Eisenack 2018). In this study, an archetype is defined as a recurrent, specific relation between diagnostic and design attributes and outcomes, taking the following form: for all cases c of a subset $\left(\mathrm{C}_{i} \subseteq \mathrm{C}\right)$ : if a set of diagnostic and design attributes $\left(\mathrm{D}_{\mathrm{i}} \subseteq \mathrm{D}\right)$ holds for all cases c, then the outcomes $\left(\mathrm{O}_{\mathrm{i}} \subseteq \mathrm{O}\right)$ are expected to hold for all cases c.

Specifically, the index $i$ indicates that multiple archetypes can hold in one case. The term "recurrent" requires an archetype to be observed in at least two cases. In other words, an archetype i covers a case $\mathrm{c}$ if $\mathrm{c} \in \mathrm{C}_{\mathrm{i}}$ and the diagnostic and design attributes $\mathrm{D}_{i}$ and the outcome attributes $\mathrm{O}_{i}$ hold for the case c (Oberlack and Eisenack 2018).

Overall, archetype analysis is a reasonable approach to analyze rural renewal. It is expected that one archetype can be used to depict several rural renewal cases and that one rural renewal case probably encompasses several archetypes. However, different from the extant literature (Oberlack et al. 2016, Oberlack 2017, Oberlack and Eisenack 2018), the archetype analysis in this study is performed on primary data instead of a meta-study. Therefore, a relatively detailed introduction to case collection, coding and data analysis is required to clarify the procedure of the archetype analysis of first-hand cases.
Case collection and coding

Cases of rural renewal were collected by the author and research partners through a joint research project between Zhejiang University and the China Institute of Land Survey and Planning. The study areas were selected according to the criteria of typicality and diversity (Gerring 2007). Thus, in light of climate features, land scarcity, socioeconomic development levels, and population, the fieldwork was conducted successively in eastern, i.e., Zhejiang Province, Jiangsu Province, Fujian Province, and Shanghai City; central, i.e., Jiangxi Province and Hubei Province; and western, Sichuan Province and Guizhou Province, China from 2011 to 2016. Ultimately, 27 rural renewal cases were collected, with nine cases from each region.

For the fieldwork in each region, general information about rural renewal in the region, such as formal policies and procedures, was initially obtained from county-level and township-level officials in charge of rural land affairs. Subsequently, semistructured interviews were conducted at the village level with stakeholders participating in or affected by rural renewal, such as government officials, village cadres, village elites, villagers, and entrepreneurs. To select the interviewees, a stakeholder-based approach was adopted (Vatn 2005). During the interviews, we mainly focused on information about the natural and socioeconomic conditions of the study areas, the processes and outcomes of rural renewal projects, and the comments provided by the interviewees. All the relevant information was carefully recorded in written form and in a consistent narrative structure (Tan and Heerink 2017, Wang and Tan 2018).

A code book was developed based on the SES framework of rural renewal (Fig. 1). Initially, the first nine cases were coded to check the feasibility and suitability of the code book. Then, the redundant codes were removed, and equivocal codes were clarified. Finally, the 27 cases were coded according to the modified code book (Table A1.1 in Appendix 1) and our own knowledge of each case gained from our fieldwork by using the MAXQDA software.

\section{Data analysis}

A two-step approach was used to extract the archetypes from the 27 coded cases. First, all the cases were categorized into three groups according to the three extant outcomes (Table 1) to ensure that the performance differences among the groups were significant. In addition, the cases in the third group were further decomposed into three subgroups according to the scale of rural renewal (Table 1) because the extant research suggests that the amount of rural construction land and the number of rural households involved exert profound effects on sustainable rural renewal (Wang and Tan 2018).

Second, a formal concept analysis (FCA) was performed with Concept Explorer software to obtain the equivalence classes of the cases within (sub)groups. Each concept lattice generated by FCA determines all equivalence classes of the cases and characterizes them by configurations of attributes with maximal size (Ganter and Wille 1999, Stumme 2002, Kaytoue et al. 2011). A class qualifies as an archetype in this study if it also fulfills the following criteria (cf. Oberlack et al. 2016, Oberlack and Eisenack 2018; see Appendix 1 for a specific example): 
Table 1. Classification of cases.

\begin{tabular}{|c|c|c|c|}
\hline & Name & Description & Criteria $^{\dagger}$ \\
\hline$\overline{\text { Group } 1}$ & $\begin{array}{l}\text { Unsustainable } \\
\text { rural renewal }\end{array}$ & $\begin{array}{l}\text { Improvement in the rural living environment with } \\
\text { limitations }\end{array}$ & The outcome is O11 only. \\
\hline Group 2 & $\begin{array}{l}\text { Semisustainable } \\
\text { rural renewal }\end{array}$ & $\begin{array}{l}\text { Only an improvement in the rural living environment } \\
\text { that fits the context-specific conditions, e.g., living } \\
\text { convention, of a rural area }\end{array}$ & The outcome is $\mathrm{O} 12$ only. \\
\hline Group 3 & $\begin{array}{l}\text { Sustainable } \\
\text { rural renewal }\end{array}$ & $\begin{array}{l}\text { Improvement in the rural living environment, rural } \\
\text { incomes, and rural vitality }\end{array}$ & The outcomes are $\mathrm{O} 12, \mathrm{O} 21$, and $\mathrm{O} 31$. \\
\hline Subgroup 3.1 & Large scale & $\begin{array}{l}\text { The size of rural construction land is over } 10 \text { ha and } \\
\text { the number of rural households involved is over } 100\end{array}$ & The diagnostic attributes contain R11 and A21. \\
\hline Subgroup 3.2 & $\begin{array}{l}\text { Large number of } \\
\text { rural households } \\
\text { involved }\end{array}$ & $\begin{array}{l}\text { The size of rural construction land is smaller than } 10 \\
\text { ha but the number of rural households involved is } \\
\text { over } 100\end{array}$ & The diagnostic attributes contain R12 and A21. \\
\hline Subgroup 3.3 & Small scale & $\begin{array}{l}\text { The size of rural construction land is smaller than } 10 \\
\text { ha and the number of rural households involved is } \\
\text { less than } 100\end{array}$ & The diagnostic attributes contain R12 and A22. \\
\hline
\end{tabular}

(1) An archetype must consist of at least one diagnostic attribute, i.e., R-variable, A-variable and I-variable, at least one design attribute, i.e., GS-variable, and at least one outcome, i.e., Ovariable, and needs to reappear in at least two cases, ensuring that archetypes originate from various cases and sources.

(2) An archetype must be interpreted by a coherent theory. Archetypes are characterized by a configuration of diagnostic, design, and outcome attributes. In addition, an archetype requires a rationale for the configuration to occur (Eisenack et al. 2019). Thus, a class qualifies as an archetype if theory can sufficiently explain the outcomes.

The following criteria aim at parsimony, and the objective is to characterize the diversity of cases without an excessive number of archetypes. Similar criteria are followed by Gotgelf, Roggero, and Eisenack, unpublished manuscript.

(3) Archetypes are considered building-blocks, suggesting that the causality displayed in an archetype should be unique and cannot be jointly explained by other archetypes. Therefore, within all the classes that meet the above two criteria, a class qualifies as an archetype if it cannot be composed of any other classes.

(4) The generality and the particularity of the archetype analysis need to be addressed, suggesting that a subarchetype is expected to provide more detailed data but not too specific or entirely repetitive information about the identified archetypes. Therefore, within all the classes that meet the criteria 1 and 2, a class qualifies as a subarchetype if it can only be composed of an identified archetype with certain additional attributes. However, the class that can be fully composed of two or more identified archetypes and subarchetypes as well as the class that can be composed of one or more identified subarchetypes with additional attributes, namely, the subarchetypes of subarchetypes, should all be excluded. Ultimately, eight archetypes covering all the cases were identified, and one to three archetypes held in each case (Appendix 2).

\section{RESULTS AND DISCUSSION}

The text below illustrates the eight identified archetypes of unsustainable, semisustainable, and sustainable rural renewal in detail as well as highlights the features of and the coherence and differences among the archetypes to demonstrate the patterns of how sustainable rural renewal emerges and why renewal efforts often fail in achieving rural sustainability. Additionally, we selected a representative case for each archetype to provide more detailed and vivid information about the practices and outcomes of rural renewal in China (Appendix 3).

\section{Unsustainable rural renewal}

Rural renewal in all cases improved the rural living environment. However, the rural renewal in some cases ( 5 of 27 cases) failed to fit the context-specific conditions and induced side effects on rural sustainable development. The interviewees, particularly rural households, complained that the traditional rural landscape had faded and that the new residential areas were situated far from their workplaces, e.g., farmland and ponds, etc. Archetype 1 illustrates this pattern of unsustainable rural renewal (Table 2).

Table 2. Archetypes for unsustainable rural renewal.

\begin{tabular}{lllc}
\hline \hline No. & Description of archetypes & Codes of (sub)archetypes & $\begin{array}{c}\text { No. of } \\
\text { cases }\end{array}$ \\
\hline 1 & $\begin{array}{l}\text { Government-led rural } \\
\text { renewal with a short-term } \\
\text { perspective }\end{array}$ & $\begin{array}{l}\text { A11-GS51-GS61-GS72- } \\
\text { I121-I322-O11 }\end{array}$ & 5 \\
1.1 & $\begin{array}{l}\text { Internal heterogeneity and } \\
\text { top-down relation }\end{array}$ & $\begin{array}{l}\text { A11-A32-GS11-GS51-GS61- } \\
\text { GS72-I121-I322-O11 }\end{array}$ & 4 \\
1.2 & $\begin{array}{l}\text { Large-scale rural renewal } \\
\text { with limited stakeholder } \\
\text { participation under high } \\
\text { complexity and specificity } \\
\text { Direct economic incentives }\end{array}$ & $\begin{array}{l}\text { RS71-A11-GS51-GS54-GS61- } \\
\text { I211-I221-I322-O11 }\end{array}$ & 4 \\
& A11-GS21-GS51-GS61- & 4 \\
\hline
\end{tabular}

${ }^{\dagger}$ Archetypes are described by their general features and subarchetypes are described by their distinctive attributes. 
Archetype 1 is characterized by a government-led mode and a short-time perspective of rural renewal. Based on a top-down relation (subarchetype 1.1), the government manipulates almost all the processes of rural renewal. Admittedly, the governmentled mode aligns with the governance demands of high specificity and internal heterogeneity (subarchetypes 1.1 and 1.2). Both the asset specificity and site specificity resulting from the large scale of rural renewal require the proper handling of the potential hazards to implementation, including high opportunity costs; the "lock-in" effect, in which the upfront investment of land assembly is meaningless without accessing all the construction land in the project area; and opportunistic behaviors of rural households, such as hold-ups (Williamson 1991, Alexander 2001). Fortunately, the government in China can afford to make an enormous investment because of its financial capacity, which is generally stronger than that of other actors; furthermore, the government can cope with the "lock-in" effect and prevent holdups and other opportunistic behaviors through coercive public power. Moreover, the government uses its public power to force stakeholders with internal heterogeneity to compromise. As a result, new rural settlements were built up in these cases. However, under the government-led mode, the absence of restrictions on coercive public power inevitably hampered individuals' interests and rights, likely inducing severe social problems. For example, social tensions occasionally occurred between the rural households reluctant to participate in rural renewal and the local government, and certain rural households living in single houses with courtyards for a long time were not accustomed to living in multistory apartment buildings. Even worse, rural households who lost land and failed to find an alternative space for livestock breeding were confronted with a greater challenge to their livelihood.

As shown in archetype 1, the government-led mode faces the uncertainty of the scheme design because decision makers normally lack local knowledge. Moreover, the government-led mode is incompatible with high complexity (subarchetype 1.2), in that stakeholder participation, especially in decision making and revenue appropriation and distribution, is excluded under the government-led mode; thus, multiple interests cannot be sufficiently considered and well coordinated. Consequently, the improved rural living environment could not easily fit the local conditions, resulting in complaints from rural households. In addition, archetype 1 further suggests that based on the government-dominated appropriation mechanism, the government can obtain major revenue from rural renewal, but the gains of rural areas are relatively limited, which is also evident in the revenue distribution records in specific cases. Therefore, government-led rural renewal fails to increase rural incomes.

Notably, archetype 1 shows that a short-term time horizon of revenue appropriation and distribution as well as direct economic incentives without any long-term considerations (subarchetype 1.3) impede rural vitality enhancement. For example, rural households obtained only a one-time monetary compensation for moving out of their old houses. In addition, most of the incremental revenue from rural construction land consolidation and redevelopment was spent on constructing rural residences, and little was used for rural industry development.

\section{Semisustainable rural renewal}

Some rural renewal projects (6 of 27 cases) only adequately improved the rural living environment, that is, the built-up new rural residences fit the context-specific conditions, and most rural households were satisfied with the new living environment. An adequately improved rural living environment achieves the basic goal of rural sustainability. Two archetypes were identified in this category (Table 3).

Table 3. Archetypes for semisustainable rural renewal.

\begin{tabular}{|c|c|c|c|}
\hline No. & Description of archetypes & Codes of (sub)archetypes & $\begin{array}{c}\text { No. of } \\
\text { cases }\end{array}$ \\
\hline 2 & $\begin{array}{l}\text { Small-scale rural renewal } \\
\text { with sufficient stakeholder } \\
\text { participation }\end{array}$ & R12-A12-GS41-GS712-O12 & 5 \\
\hline 2.1 & Low uncertainty & $\begin{array}{l}\text { R12-A12-GS41-GS712- } \\
\text { I122-O12 }\end{array}$ & 4 \\
\hline 2.2 & Rural household provision & $\begin{array}{l}\text { R12-A12-GS41-GS54- } \\
\text { GS712-O12 }\end{array}$ & 3 \\
\hline 2.3 & $\begin{array}{l}\text { Low complexity and site } \\
\text { specificity }\end{array}$ & $\begin{array}{l}\text { R12-A12-A22-GS41-GS712- } \\
\text { I112-I222-I312-O12 }\end{array}$ & 3 \\
\hline 3 & $\begin{array}{l}\text { Rural renewal with } \\
\text { government-village } \\
\text { cooperation }\end{array}$ & A11-A12-GS12-O12 & 5 \\
\hline 3.1 & $\begin{array}{l}\text { Government-village } \\
\text { cooperation with a short- } \\
\text { term perspective }\end{array}$ & $\begin{array}{l}\text { R12-R22-A11-A12-GS12- } \\
\text { GS21-GS41-GS712-GS73- } \\
\text { GS8-I322-O12 }\end{array}$ & 4 \\
\hline 3.2 & $\begin{array}{l}\text { High complexity, low } \\
\text { uncertainty and high site } \\
\text { specificity }\end{array}$ & $\begin{array}{l}\text { A11-A12-A21-GS12-I111- } \\
\text { I122-I221-I311-O12 }\end{array}$ & 3 \\
\hline
\end{tabular}

Archetype 2 highlights that the mechanisms of transparent information and inclusive decision making are greatly important to adequate improvement of the rural living environment. Transparent information related to rural renewal creates favorable conditions for inclusive decision making. The mechanisms in favor of stakeholder participation can exploit dispersed local knowledge (Oates 1999) and then reduce the uncertainty but increase the rationality of the scheme design (subarchetype 2.1). Therefore, in these cases, townhouses rather than the multistory apartment buildings were built, and the new settlements were in proximity to farmers' workplaces. Moreover, archetype 2 suggests that the small scale of rural renewal could be a double-edged sword for sustainable rural renewal. On the one hand, the small scale enables rural sectors to fully cover the cost of rural renewal (subarchetype 2.2). Consequently, a third party is unable to intervene in rural renewal by providing funds. Furthermore, a small scale is conducive to designing an appropriate scheme and implementing the scheme smoothly, reducing the complexity of the scheme design and revenue appropriation and distribution as well as the site specificity of implementation (subarchetype 2.3). On the other hand, during the fieldwork, we also found that smallscale rural land consolidation and redevelopment normally could not generate sufficient space and revenue for rural industry development. Consequently, the goals of increasing rural incomes and enhancing rural vitality could rarely be fulfilled because of the small scale of rural renewal.

Archetype 3 illustrates that even if the government intervenes in rural renewal, cooperative governance, particularly a horizontal relation between the government and village actors, is beneficial 
Table 4. Archetypes for sustainable rural renewal.

\begin{tabular}{|c|c|c|c|}
\hline No. & Description of archetypes & Codes of (sub)archetypes & No. of cases \\
\hline 4 & $\begin{array}{l}\text { Government participation in large-scale rural renewal with a } \\
\text { long-term perspective }\end{array}$ & R11-A11-A21-GS22-I111-I211-I221-I311-I321-O12-O21-O31 & 7 \\
\hline 4.1 & Sufficient stakeholder participation & $\begin{array}{l}\text { R11-A11-A21-GS22-GS41-GS712-I111-I211-I221-I311-I321- } \\
\text { O12-O21-O31 }\end{array}$ & 6 \\
\hline 5 & $\begin{array}{l}\text { Self-organized large-scale rural renewal with a long-term } \\
\text { perspective }\end{array}$ & $\begin{array}{l}\text { R11-A12-A21-GS22-GS41-GS712-GS73-GS8-I111-I122- } \\
\text { I211-I221-I311-I321-O12-O21-O31 }\end{array}$ & 5 \\
\hline 5.1 & Sufficient social capital & $\begin{array}{l}\text { R11-A12-A21-A5-GS12-GS21-GS22-GS41-GS54-GS712- } \\
\text { GS73-GS8-I111-I122-I211-I221-I311-I321-O12-O21-O31 }\end{array}$ & 4 \\
\hline 5.2 & Peri-urban areas and good accessibility & $\begin{array}{l}\text { R11-R21-R22-A12-A21-GS22-GS41-GS712-GS73-GS8-I111- } \\
\text { I122-I211-I221-I311-I321-O12-O21-O31 }\end{array}$ & 3 \\
\hline 6 & $\begin{array}{l}\text { Enterprise participation in large-scale rural renewal with a } \\
\text { long-term perspective }\end{array}$ & $\begin{array}{l}\text { R11-A13-A21-GS22-GS41-GS712-I111-I211-I221-I311-I321- } \\
\text { O12-O21-O31 }\end{array}$ & 4 \\
\hline 6.1 & Good accessibility & $\begin{array}{l}\text { R11-R22-A13-A21-GS22-GS41-GS712-I111-I211-I221-I311- } \\
\text { I321-O12-O21-O31 }\end{array}$ & 3 \\
\hline 6.2 & Enterprise-village cooperation & $\begin{array}{l}\text { R11-A13-A21-GS21-GS22-GS41-GS54-GS712-I111-I211- } \\
\text { I221-I311-I321-O12-O21-O31 }\end{array}$ & 3 \\
\hline 7 & $\begin{array}{l}\text { Government participation in rural renewal with a large } \\
\text { number of rural households involved and a long-term } \\
\text { perspective }\end{array}$ & $\begin{array}{l}\text { R12-A11-A21-GS12-GS22-GS51-GS712-I111-I122-I211- } \\
\text { I221-I311-I321-O12-O21-O31 }\end{array}$ & 3 \\
\hline 7.1 & Peri-urban areas & $\begin{array}{l}\text { R12-R21-A11-A21-GS12-GS22-GS51-GS712-GS72-I111- } \\
\text { I122- I211-I221-I311-I321-O12-O21-O31 }\end{array}$ & 2 \\
\hline 7.2 & Coordination mechanism & $\begin{array}{l}\text { R12-A11-A12-A21-A31-GS12-GS22-GS41-GS51-GS712- } \\
\text { GS8-I111-I122-I211-I221-I311-I321-O12-O21-O31 }\end{array}$ & 2 \\
\hline 8 & $\begin{array}{l}\text { Self-organized small-scale rural renewal with a long-term } \\
\text { perspective }\end{array}$ & $\begin{array}{l}\text { R12-A12-A22-A31-A5-GS12-GS22-GS32-GS41-GS712- } \\
\text { GS73-GS8-I112-I122-I222-I312-I321-O12-O21-O31 }\end{array}$ & 4 \\
\hline 8.1 & Distinctive land quality and local leadership/entrepreneurship & $\begin{array}{l}\text { R12-R31-A12-A22-A31-A4-A5-GS12-GS22-GS32-GS41- } \\
\text { GS712-GS73-GS8-I112-I122-I222-I312-I321-O12-O21-O31 }\end{array}$ & 3 \\
\hline 8.2 & Peri-urban areas, good accessibility, and internal homogeneity & $\begin{array}{l}\text { R12-R21-R22-A12-A22-A31-A5-GS12-GS22-GS32-GS41- } \\
\text { GS712-GS73-GS8-I112-I122-I212-I222- I312-I321-O12-O21- } \\
\text { O31 }\end{array}$ & 2 \\
\hline
\end{tabular}

to adequate improvement of the rural living environment. The government and village actors are formally independent of each other, suggesting that village actors are not subordinated to the government and the government is not an exclusive decision maker. Thus, the horizontal relation between the government and village actors provides an institutional basis for stakeholder participation and decentralization (subarchetype 3.1). Consequently, the rural sector is no longer forced to accept decisions from a single central authority, e.g., the government, that are probably inappropriate for local situations. Thus, the government-village cooperative mode can reduce the uncertainty of the scheme design and align with high complexity, and the necessary government intervention can handle the hazards of high site specificity, such as halting hold-ups by coercive public power (subarchetype 3.2). In addition, the side effects of coercive public power on individuals can be mitigated or even avoided because of the aforementioned cooperative governance between the government and village due to the horizontal relation and decentralization. Notably, similar to archetype 1, subarchetype 3.1 underscores that certain instances of rural renewal are unable to effectively upgrade rural vitality because of direct economic incentives and the shortterm time horizon of revenue disposition.

\section{Sustainable rural renewal}

Sustainable rural renewal emerged in certain areas ( 16 of 27 cases), simultaneously improving the rural living environment, increasing rural incomes, and enhancing rural vitality. Five archetypes describe its underlying logic (Table 4).
These archetypes share two major features. First, as shown in all the five archetypes, the revenue from rural renewal is appropriated and distributed based on a long-term time horizon in the pursuit of sustainability. For instance, the revenue was used to establish and strengthen agricultural cooperatives or collective-owned enterprises, and rural households could continuously obtain dividends in return. Additionally, long-term incentives, including job opportunities, social security, and periodic revenue dividends, were employed to reduce livelihood hazards after renewal and to diversify rural income sources. Second, subarchetypes 5.2, 6.1, $7.1,8.1$, and 8.2 jointly emphasize that a locational advantage or distinctive rural construction land quality, e.g., a unique landscape, could be an endowment for rural sustainability, especially for small-scale rural renewal (compared with archetype 2 ). In practice, the land revenue from the locational advantage directly increased rural incomes; furthermore, small-scale rural renewal with locational advantages was more appealing to investors than ordinary small-scale rural renewal. Additionally, hotels and other leisure facilities compatible with the local landscape were constructed to properly utilize tourism resources in specific cases (Fig. A3.4 in Appendix 3). Because of the operation of tourism facilities, off-farm jobs were created, and rural tourism was promoted, which in turn generated sustainable revenue for the rural areas and enhanced rural vitality.

The first three archetypes elaborate the determinants of sustainable rural renewal, given that the project covered a large amount of rural construction land and a large number of rural households. More specifically, archetype 4 highlights that 
government participation rather than complete control is sufficient to solve the financing issues resulting from high asset specificity and restrain the opportunistic behaviors caused by high site specificity in large-scale rural renewal. The mechanisms supporting stakeholder participation, i.e., transparent information and inclusive decision making, fit the high complexity (subarchetype 4.1); furthermore, in addition to adequately improving the rural living environment (see archetypes 2 and 3), these mechanisms are indispensable for rural wealth and rural vitality. In contrast to the government-led mode, the socioeconomic development claims of the rural sector are more likely to be considered and eventually fulfilled because rural households or their representatives are granted the right to express their interests during a more decentralized decision-making process. Apparently, the government-participated mode shows a similar competence but avoids the negative effects of the government-led mode on rural sustainability (compared with archetype 1).

Archetype 5 indicates that self-organization is able to facilitate rural sustainability in the context of large scale rural renewal. Generally speaking, self-organization aligns with the high complexity and specificity and can reduce the uncertainty induced by the large scale of rural renewal; furthermore, self-organization enables rural households to make their own decisions, appropriate and distribute revenue rationally, and shift to a suitable development path. Concretely, the self-organized mode shares several key components with the governance modes in archetype 4, which fits the high complexity of rural renewal. Moreover, selforganized rural renewal has its own features. First, rural renewal is initiated, led, and organized by village leaders/elites based on the collective action of rural households. Second, although the government may give advice regarding rural renewal in certain cases, the decisions are still made by local decision makers, i.e., village leaders/elites and rural households based on the majority or unanimity principle, thereby further reducing the uncertainty of rural renewal. Third, self-organization restrains opportunistic behaviors and other hazards triggered by high specificity through a well-functioning coordination mechanism. For instance, the renewal scheme was collectively discussed and approved through a village council or a village representative assembly. The members of the village council or the village representatives were the coordinators of project implementation and devoted to solving disputes among rural households (Jing and Zhang 2017). Fourth, the emergence of self-organized rural renewal relies heavily on sufficient social capital in the rural community (subarchetype 5.1). Sufficient social capital along with the other two conditions presented in archetype 8 can reduce the cost of collective action.

Archetype 6 illustrates the competence of the enterpriseparticipation mode in rural sustainability. Relying on a governance system similar to that of the former two archetypes, the enterprise-participation mode aligns with the governance demands of large-scale rural renewal. Particularly, regarding the high asset and site specificity, enterprises cooperate with rural households to cover the cost of rural renewal, and combine direct incentives with long-term incentives to handle hold-ups and promote the project implementation (subarchetype 6.2). In practice, we found that a win-win situation emerged. Enterprises gained long-term revenue from investment in a new type of industry, e.g., rural tourism, and the rural sector obtained offfarm job opportunities and annual dividends.
The final two archetypes reveal the determinants of sustainable rural renewal when the amount of rural construction land is small and/or the number of rural households involved is small. Concretely, archetype 7 and subarchetype 7.2 show that a small size of rural construction land possessed by many rural households aggravates asset and site specificity, in that every single actor tends to be a free rider in covering the cost and it is challenging to assemble the fragmented land property rights. Government participation functioning as an external coercive power along with an internal coordination mechanism among rural households, such as a village council or a village representative assembly, can mitigate the above governance hazards of sustainable rural renewal. In addition, similar to the situations in archetypes 3 and 4, the coercive power of the government is restrained under a decentralized governance system, leading the government to act as a participator rather than a dominator; thus, individuals' interests and rights can be respected and protected. Archetype 8 further highlights the competence of self-organized rural renewal in rural sustainable development. Moreover, subarchetypes 8.1 and 8.2 display two more preconditions for self-organization, namely, local leadership/entrepreneurship and internal homogeneity.

\section{CONCLUSION}

Given the goals of rural sustainability, this study revealed the underlying patterns of sustainable rural renewal in China by using an archetype approach based on primary data from 27 cases from the eastern, central, and western regions of China. In total, eight archetypes were identified, of which one concerns unsustainable rural renewal, two concern semisustainable rural renewal, and five concern sustainable rural renewal (Tables 2-4 and Table A1.2). The overarching implications drawn from these eight archetypes are presented below.

First, in the pursuit of sustainable rural renewal, the governance system should be aligned with the attributes of rural land resources, the characteristics of actors, and the properties of interactions. An appropriately devised governance system can meet the governance demands of the context-specific conditions of SES. By contrast, a misalliance of the above components could induce unsustainable rural renewal. In addition, various hybrid governance systems can fit the large scale of rural renewal and its high specificity, and the government-led mode is not the only possible solution. These findings support the existing arguments regarding the governance fit and performance difference in rural renewal (Wang and Tan 2018).

Second, a governance system with decentralized features, involving government, village actors, and enterprises, contributes to sustainable rural renewal. A horizontal network structure and sufficient stakeholder participation can adequately improve the rural living environment. A decentralized governance system is also beneficial for increasing rural incomes and enhancing rural vitality. Furthermore, self-organized rural renewal can facilitate rural sustainability, and its emergence depends heavily on the favorable characteristics of actors (Ostrom 2009), including internal homogeneity, local leadership/entrepreneurship, and sufficient social capital. The above findings corroborate the determinants of sustainable rural collective action identified in the literature (e.g., Ostrom 2009, Bassi and Carestiato 2016, Schmidt et al. 2016), demonstrate the potentials of polycentric 
governance in rural development, and, to some extent, justify the views of fiscal federalism and the adaptability of polycentric governance in the politically centralized institutional context of China (Ostrom et al. 1993, Oates 1999, Ostrom 2010).

Third, a long-term perspective of rural renewal, including longterm incentives and a long-term time horizon of revenue disposition, contributes to rural sustainability. In contrast, rural renewal with a short-term time horizon usually fails to markedly increase rural incomes and enhance rural vitality. Additionally, the attributes of rural construction land resources affect the sustainability of rural renewal. A distinctive land resource endowment, i.e., locational advantages and a unique landscape, is vital for sustainable rural renewal, particularly for small-scale rural renewal.

Admittedly, these archetypes were obtained from 27 cases and may not precisely depict the whole picture of sustainable rural renewal. Thus, the inclusion of more cases in subsequent research is expected to confirm the present conclusions and broaden our theoretical and practical understanding. However, this research makes several contributions. First, this study adapted and specified the SES framework to analyze rural renewal in China. Second, this study provided a somewhat detailed procedure to conduct an archetype analysis of first-hand cases. Third, this study explicitly described the archetypical patterns of sustainable rural renewal, which reinforces the theoretical findings concerning rural collective actions, fiscal federalism, and polycentric governance with the empirical evidence from China, a typical RDA regime. Fourth, the implications of the archetypical patterns may benefit China and other regions pursuing rural sustainability.

Responses to this article can be read online at: http://www.ecologyandsociety.org/issues/responses. php/11069

\section{Acknowledgments:}

This research has received financial support from the Natural Science Foundation of China through project No. 71573231, the Social Science Foundation of China through project No. 16ZDA020, No. 14AZD028, No. 13AZD012, and No. 14ZDA039, the China Scholarship Council through project No. 201706320201, andZhejiang University Academic Awardfor Outstanding Doctoral Candidates through project No. 2018011. The authors would like to thank the funding organizations for the grants. We also want to thank our partners from Zhejiang University and the China Institute of Land Survey and Planning for their excellent jobs in the fieldwork and for allowing us to use all the materials from the joint project.

\section{LITERATURE CITED}

Alexander, E. R. 2001. A transaction-cost theory of land use planning and development control: toward the institutional analysis of public planning. Town Planning Review 72:45-75. https://doi.org/10.3828/tpr.2001.72.1.45

Bassi, I., and N. Carestiato. 2016. Common property organisations as actors in rural development: a case study of a mountain area in Italy. International Journal of the Commons 10 (1):363-386. https://doi.org/10.18352/ijc.608

Chen, X. 2010. Issues of China's rural development and policies. China Agricultural Economic Review 2(3):233-239. https://doi. org/10.1108/17561371011078390

Chen, X. 2013. Agriculture and rural development: current situation and problems. Journal of Nanjing Agricultural University 13:1-10.

Eisenack, K., M. Lüdeke, and J. Kropp. 2006. Construction of archetypes as a formal method to analyze social-ecological systems. In Proceedings of the Institutional Dimensions of Global Environmental Change Synthesis Conference. Bali, Indonesia. [online] URL:https://www.uni-oldenburg.de/fileadmin/user upload/ wire/fachgebiete/envdev/download/arch-eisenack3.pdf

Eisenack, K., S. Villamayor-Tomas, G. Epstein, C. Kimmich, N. Magliocca, D. Manuel-Navarrete, C. Oberlack, M. Roggero, and D. Sietz. 2019. Design and quality criteria for archetype analysis. Ecology and Society 24(3):6. https://doi.org/10.5751/ES-10855-240306

Fang, B., C. Wu, and L. Yang. 2007. The case study of rural residential area consolidation and discussion on its development path. Journal of Anhui Agriculture Science 35:799-800.

Fang, Y., K. Shi, and C. Niu. 2016. A comparison of the means and ends of rural construction land consolidation: case studies of villagers' attitudes and behaviours in Changchun City, Jilin province, China. Journal of Rural Studies 47:459-473. https://doi. org/10.1016/j.jrurstud.2016.04.007

Ganter, B., and R. Wille. 1999. Formal concept analysis: mathematical foundations. Springer, Berlin, Germany.

Gerring, J. 2007. Case study research: principles and practices. Cambridge University Press, New York, New York, USA.

Griggs, D., M. Stafford-Smith, O. Gaffney, J. Rockström, M. C. Öhman, P. Shyamsundar, W. Steffen, G. Glaser, N. Kanie, I. Noble. 2013. Policy: sustainable development goals for people and planet. Nature 495:305-307. https://doi.org/10.1038/495305a

Guo, Y., Y. Xiao, and Q. Yuan. 2017. The redevelopment of periurban villages in the context of path-dependent land institution change and its impact on Chinese inclusive urbanization: the case of Nanhai, China. Cities 60:466-475. https://doi.org/10.1016/j. cities.2016.05.010

Hagedorn, K. 2008. Particular requirements for institutional analysis in nature-related sectors. European Review of Agricultural Economics 35(3):357-384. https://doi.org/10.1093/erae/jbn019

Huang, Q., M. Li, Z. Chen, and F. Li. 2011. Land consolidation: an approach for sustainable development in rural China. Ambio 40(1):93-95. https://doi.org/10.1007/s13280-010-0087-3

Hwang, D., and W. P. Stewart. 2017. Social capital and collective action in rural tourism. Journal of Travel Research 56(1):81-93. https://doi.org/10.1177/0047287515625128

Jelsma, I., M. Slingerland, K. E. Giller, and J. Bijman. 2017. Collective action in a smallholder oil palm production system in Indonesia: the key to sustainable and inclusive smallholder palm oil? Journal of Rural Studies 54:198-210. https://doi.org/10.1016/ j.jrurstud.2017.06.005 
Jing, Y., and L. Zhang. 2017. The changing institutional space regarding roles and behavior of village leaders: an evolution from villagers' autonomy to the power list. Journal of Chinese Governance 2(3):271-291. https://doi.org/10.1080/23812346.2017.1342391

Kaytoue, M., S. O. Kuznetsov, and A. Napoli. 2011. Revisiting numerical pattern mining with formal concept analysis. In IJCAI Proceedings-International Joint Conference on Artificial Intelligence. [online] URL: http://www.aaai.org/ocs/index.php/ IJCAI/IJCAI11/paper/download/3151/3444

König, H. J., L. Zhen, K. Helming, S. Uthes, L. Yang, X. Cao, and H. Wiggering. 2014. Assessing the impact of the sloping land conversion programme on rural sustainability in Guyuan, Western China. Land Degradation \& Development 25(4):385-396. https://doi.org/10.1002/ldr.2164

Li, B. 2018. Top-down place-based competition and award: local government incentives for non-GDP improvement in China. Journal of Chinese Governance 3(4):397-418. https://doi. org/10.1080/23812346.2018.1516418

Li, Y., Y. Liu, H. Long, and W. Cui. 2014. Community-based rural residential land consolidation and allocation can help to revitalize hollowed villages in traditional agricultural areas of China: evidence from Dancheng County, Henan Province. Land Use Policy 39:188-198. https://doi.org/10.1016/j.landusepol.2014.02.016

Liu, Y., F. Fang, and Y. Li. 2014. Key issues of land use in China and implications for policy making. Land Use Policy 40:6-12. https://doi.org/10.1016/j.landusepol.2013.03.013

Liu, Y. S., J. Y. Wang, and H. L. Long. 2010. Analysis of arable land loss and its impact on rural sustainability in southern Jiangsu Province of China. Journal of Environmental Management 91 (3):646-653. https://doi.org/10.1016/j.jenvman.2009.09.028

Long, H. 2014. Land consolidation: an indispensable way of spatial restructuring in rural China. Journal of Geographical Sciences 24(2):211-225. https://doi.org/10.1007/s11442-014-1083-5

Long, H., Y. Li, Y. Liu, M. Woods, and J. Zou. 2012. Accelerated restructuring in rural China fueled by 'increasing vs. decreasing balance' land-use policy for dealing with hollowed villages. Land Use Policy 29(1):11-22. https://doi.org/10.1016/j.landusepol.2011.04.003

Macken-Walsh, Á., and C. Curtin. 2013. Governance and rural development: the case of the rural partnership programme (RPP) in post-socialist Lithuania. Sociologia Ruralis 53(2):246-264. https://doi.org/10.1111/j.1467-9523.2012.00578.x

National Bureau of Statistics of China (NBSC). 2018. 2017 Statistical bulletin of national economic and social development. National Bureau of Statistics of China, Beijing, China. [online] URL: http://www.stats.gov.cn/tjsj/zxfb/201802/t20180228_1585631. $\underline{\mathrm{html}}$

Oates, W. E. 1999. An essay on fiscal federalism. Journal of Economic Literature 37(3):1120-1149. https://doi.org/10.1257/ jel.37.3.1120

Oberlack, C. 2017. Diagnosing institutional barriers and opportunities for adaptation to climate change. Mitigation and Adaptation Strategies for Global Change 22(5):805-838. https:// doi.org/10.1007/s11027-015-9699-Z
Oberlack, C., and K. Eisenack. 2014. Alleviating barriers to urban climate change adaptation through international cooperation. Global Environmental Change 24:349-362. https://doi.org/10.1016/ j.gloenvcha.2013.08.016

Oberlack, C., and K. Eisenack. 2018. Archetypical barriers to adapting water governance in river basins to climate change. Journal of Institutional Economics 14:527-555. https://doi. org/10.1017/S1744137417000509

Oberlack, C., D. Sietz, E. Bürgi Bonanomi, A. De Bremond, J. Dell'Angelo, K. Eisenack, E. C. Ellis, G. Epstein, M. Giger, A. Heinimann, C. Kimmich, M. T. J. Kok, D. Manuel-Navarrete, P. Messerli, P. Meyfroidt, T. Václavík, and S. Villamayor-Tomas. 2019. Archetype analysis in sustainability research: meanings, motivations, and evidence-based policy making. Ecology and Society 24(2):26. https://doi.org/10.5751/ES-10747-240226

Oberlack, C., L. Tejada, P. Messerli, S. Rist, and M. Giger. 2016. Sustainable livelihoods in the global land rush? Archetypes of livelihood vulnerability and sustainability potentials. Global Environmental Change 41:153-171. https://doi.org/10.1016/j. gloenvcha.2016.10.001

Osborne, S., R. Beattie, and A. Williamson. 2006. The impact of local voluntary and community sector infrastructure on community involvement in rural regeneration partnerships. Public Money and Management 26(4):235-242. https://doi. org/10.1111/j.1467-9302.2006.00531.x

Osborne, S., A. Williamson, and R. Beattie. 2004. Community involvement in rural regeneration partnerships: exploring the rural dimension. Local Government Studies 30(2):156-181. https:// doi.org/10.1080/0300393042000267218

Ostrom, E. 1990. Governing the commons: the evolution of institutions for collective action. Cambridge University Press, Cambridge, UK.

Ostrom, E. 2005. Understanding institutional diversity. Princeton University Press, Princeton, New Jersey, USA. https://doi. org/10.2307/j.ctt7s $7 \mathrm{wm}$

Ostrom, E. 2009. A general framework for analyzing sustainability of social-ecological systems. Science 325 (5939):419-422. https://doi.org/10.1126/science.1172133

Ostrom, E. 2010. Polycentric systems for coping with collective action and global environmental change. Global Environmental Change 20(4):550-557. https://doi.org/10.1016/j.gloenvcha.2010.07.004

Ostrom, E., L. Schroeder, and S. Wynne. 1993. Institutional incentives and sustainable development: infrastructure policies in perspective. Westview Press, Boulder, Colorado, USA.

Schmidt, C. M., I. D. Cielo, K. R. Wenningkamp, and M. Tomio. 2016. Collective actions in sustainable rural tourism: a case study of the western region of Paraná. Systems Research and Behavioral Science 33:249-258. https://doi.org/10.1002/sres.2380

Stumme, G. 2002. Efficient data mining based on formal concept analysis. Pages 534-546 in International Conference on Database and Expert Systems Applications. Springer, Berlin, Germany. https://doi.org/10.1007/3-540-46146-9_53 
Tan, R., and N. Heerink. 2017. Public and self-organized land readjustment in rural China: a comparison. Journal of Rural Studies 53:45-57. https://doi.org/10.1016/j.jrurstud.2017.04.006

Tang, J., Q. Wang, and R. Tan. 2014. Rural land policies reform in the context of new-type urbanization. China Social Sciences Press, Beijing, China.

Tang, J., Q. Wang, and R. Tan. 2016. Theory and practice of construction land redevelopment in the context of new-type urbanization. China Social Sciences Press, Beijing, China.

Tang, Y., R. J. Mason, and Y. Wang. 2015. Governments' functions in the process of integrated consolidation and allocation of rural-urban construction land in China. Journal of Rural Studies 42:43-51. https://doi.org/10.1016/j.jrurstud.2015.09.010

The 16th Central Committee of the Communist Party of China (CCCPC). 2005. The bulletin of the 5th plenary session of the 16th Central Committee of the Communist Party of China. The Central Committee of the Communist Party of China, Beijing, China. [online] URL: http://cpc.people.com.cn/GB/64162/134580/141447/

The 19th Central Committee of the Communist Party of China (CCCPC). 2017. The bulletin of the 19th National Congress of the Communist Party of China. The Central Committee of the Communist Party of China, Beijing, China. [online] URL: http:// www.xinhuanet.com/politics/19cpcnc/2017-10/27/c 1121867529. $\underline{\mathrm{htm}}$

The European Union (EU). 2014. Rural development (2014-2020). EU, Brussels, Belgium. [online] URL: https://ec. europa.eu/agriculture/rural-development-2014-2020 en

The United Nations (UN). 2015. About the sustainable development goals. UN, New York, New York, USA. [online] URL:https://www.un.org/sustainabledevelopment/sustainabledevelopment-goals/

Vatn, A. 2005. Institutions and the environment. Edward Elgar, Cheltenham, UK.

Wang, R., and R. Tan. 2018. Rural renewal of China in the context of rural-urban integration: governance fit and performance differences. Sustainability 10(2):393-414. https://doi.org/10.3390/ $\underline{\text { su10020393 }}$

Williamson, O. E. 1991. Comparative economic organization: the analysis of discrete structural alternatives. Administrative Science Quarterly 36:269-296. https://doi.org/10.2307/2393356

$\mathrm{Xu}, \mathrm{C}$. 2011. The fundamental institutions of China's reforms and development. Journal of Economic Literature 49 (4):1076-1151. https://doi.org/10.1257/jel.49.4.1076

Xu, W., N. Khoshroo, H. Bjornlund, and Y. Yin. 2014. Effects of "Grain for Green" reforestation program on rural sustainability in China: an AHP approach to peasant consensus of public land use policies. Stochastic Environmental Research and Risk Assessment 28(4):867-880. https://doi.org/10.1007/s00477-012-0592$\mathrm{y}$

Yang, X., and J. Yan. 2018. Top-level design, reform pressures, and local adaptations: an interpretation of the trajectory of reform since the 18th CPC Party Congress. Journal of Chinese Governance 3(1):25-48. https://doi.org/10.1080/23812346.2018.1428075 


\section{Appendix 1}

Supplementary Material of Archetype Analysis on Rural Renewal in China

Table A1.1: Code book

\begin{tabular}{|c|c|c|}
\hline Code & Description & \\
\hline $\mathrm{R}$ & \multicolumn{2}{|c|}{ Resource system and resource units } \\
\hline $\mathrm{R} 1$ & Size & $\begin{array}{l}\text { The sizes of rural construction land in the cases } \\
\text { are categorized into two groups, with a } \\
\text { sufficiently large size difference between the } \\
\text { groups. }\end{array}$ \\
\hline $\mathrm{R} 11$ & Large & $\begin{array}{l}\text { The sizes of rural construction land in this group } \\
\text { are larger than } 10 \text { ha. }\end{array}$ \\
\hline $\mathrm{R} 12$ & Small & $\begin{array}{l}\text { The sizes of rural construction land in this group } \\
\text { are smaller than } 10 \text { ha. }\end{array}$ \\
\hline $\mathrm{R} 2$ & Location & $\begin{array}{l}\text { The location conditions of rural construction } \\
\text { land. }\end{array}$ \\
\hline $\mathrm{R} 21$ & Peri-urban areas & $\begin{array}{l}\text { Rural construction land is reportedly situated at } \\
\text { urban fringes. }\end{array}$ \\
\hline $\mathrm{R} 22$ & Good accessibility & $\begin{array}{l}\text { Rural construction land is reportedly in proximity } \\
\text { to transportation lines (e.g., main roads and } \\
\text { highways) or transportation nodes (e.g., airports } \\
\text { and train stations). }\end{array}$ \\
\hline $\mathrm{R} 23$ & Remote areas & $\begin{array}{l}\text { Rural construction land is reportedly distant from } \\
\text { urban areas. }\end{array}$ \\
\hline R3 & Quality & The quality of the rural construction land. \\
\hline $\mathrm{R} 31$ & Distinctive quality & $\begin{array}{l}\text { The area is endowed with certain advantages, } \\
\text { such as a unique landscape. }\end{array}$ \\
\hline A & Actors & \\
\hline A1 & Type & $\begin{array}{l}\text { The actors who participate in rural renewal apart } \\
\text { from rural households. }\end{array}$ \\
\hline A11 & Government & \\
\hline A12 & Village leaders/elites & \\
\hline A13 & Enterprise & \\
\hline $\mathrm{A} 2$ & Size & $\begin{array}{l}\text { The numbers of rural households involved in } \\
\text { rural renewal in the cases are categorized into } \\
\text { two groups, with a sufficiently large numerical } \\
\text { difference between the groups. }\end{array}$ \\
\hline A 21 & Large & $\begin{array}{l}\text { The numbers of rural households in this group are } \\
\text { greater than } 100 \text {. }\end{array}$ \\
\hline A 22 & Small & $\begin{array}{l}\text { The numbers of rural households in this group are } \\
\text { smaller than } 100 \text {. }\end{array}$ \\
\hline A3 & $\begin{array}{l}\text { Internal homogeneity or } \\
\text { heterogeneity }\end{array}$ & \\
\hline
\end{tabular}


A31 Internal homogeneity

A32 Internal heterogeneity

A4 Leadership/

entrepreneurship

A5 Social capital

GS Governance system

GS1 Network structure

GS11 Vertical relation

GS12 Horizontal relation

GS2 Incentive mechanism

GS21 Direct economic incentive

GS22 Long-term incentive

GS3 Control mechanism

GS31 Administrative control

GS32 Community control

GS4 Information mechanism

GS41 Information transparency

GS42 Information asymmetry

GS5 Provision mechanism

GS51 Government

GS52 Village leaders/elites

GS53 Enterprise

GS54 Rural households
The actors share similar and compatible beliefs, interests and priorities in regard to rural renewal. The actors have divergent and incompatible beliefs, interests and priorities in regard to rural renewal.

A member of a rural community who has entrepreneurial skills or is respected as a local leader.

Rural households have formed a reciprocal connection or cooperative relation and trust each other.

The relation among actors.

A top-down hierarchical relation among actors.

Actors are formally independent of each other, without a single central authority.

Operational rules motivate stakeholders to participate and drive rural renewal.

The stakeholders who participate in rural renewal can gain a monetary reward and/or subsidy.

The stakeholders who participate in rural renewal can gain jobs, social security and/or other long-term benefits.

Operational rules force stakeholders to compromise and enforce rural renewal.

The administrative commands from an external authority (i.e., the government) are adopted.

The agreed-upon monitoring and sanctioning capabilities in a rural community are adopted.

Operational rules specify the channels of communication among actors and what information (e.g., planning, cost and benefit) must, may, or must not be shared.

Information is communicated and shared broadly.

Information channels are blocked, and informational advantages are created.

Operational rules specify the actor(s) who should cover the cost of rural renewal. 
GS6 Appropriation mechanism

GS61 Government

GS62 Village leaders/village elites

GS63 Enterprise

GS7 Decision-making mechanism

GS71 Eligibility

GS711 Limited participation

GS712 Inclusive participation

GS72 Centralization

GS73 Decentralization

$\begin{array}{ll}\text { GS8 } & \begin{array}{l}\text { Coordination } \\ \text { mechanism }\end{array} \\ \text { I } & \begin{array}{l}\text { Interactions } \\ \text { I1 }\end{array} \\ \text { Scheme design }\end{array}$

I11 Complexity

I111 High
Operational rules specify the actor(s) who can benefit from rural renewal apart from rural households.

Collective choice rules specify the actors involved in a decision-making process (scheme design, revenue appropriation and distribution, etc.) and manners in which decisions are made.

The set of actors who are eligible to participate in a decision-making process.

The eligibility of stakeholders to participate in decision-making is limited.

The eligibility of stakeholders to participate in decision-making is broad.

Decision-making is driven in a hierarchical and top-down manner.

Decision-making is driven in a decentralized manner based on the majority or unanimity principle.

Collective choice rules ensure that stakeholders can claim their own interests, negotiate equally with each other and ultimately reach a consensus.

The guidelines and general plan for rural renewal, such as the targets, scale, routes and arrangements, are determined and decided.

As rural renewal is a systematic process, different economic, social and ecological relations should be incorporated into the scheme design. If the scheme is not sufficiently rational and subsequently causes disputes, then the project will be difficult to implement, and the performance will suffer.

The scheme should be compatible with the interests and demands of a large number of rural households and/or those of the ecological system involved in a large size of rural land, thus increasing the difficulty of rationalizing. 
I112 Low

I12 Uncertainty

I121 High

I122 Low

I2 Implementation

I21 Asset specificity

I211 High

I212 Low

I22 Site specificity

I221 High

I222 Low
The scheme should be compatible with the interests and demands of a small number of rural households and those of the ecological system involved in a small size of rural land, thus reducing the difficulty of rationalizing.

The scheme design confronts the uncertainty originating from the cognitive limitations (e.g., bounded rationality and incomplete information) of decision-makers.

The decision-makers have insufficient or even a lack of knowledge and experience regarding scheme design.

The decision-makers have sufficient local knowledge and relevant experience regarding scheme design.

The funds for rural renewal are assembled and the project scheme is enforced.

The asset occupied by rural renewal is unavailable to other alternative uses.

Rural renewal reportedly requires a large amount of money and/or a long duration of investment.

Rural renewal reportedly requires an amount of money that is not very large and a duration of investment that is not very long.

The implementation of the rural renewal depends on construction land with a specific location, meaning that if all the land in the project area is not accessed to enforce rural renewal, the former efforts of land assembly will be in vain. In addition, once a land owner resorts to hold-up, a developer who has assembled part of the land will suffer from a project delay.

The large scale of the renewal requires the developer to assemble a large size of land and/or to reach agreements with a large number of rural households; thus, the hazard of hold-up arises.

Renewal that is not on a very large scale requires the developer to assemble a small size of land and to reach agreements with a small number of rural households; thus, the hazard of hold-up will be not as severe. 
I3 Revenue appropriation and distribution

I31 Complexity

I311 High

I312 Low

I32 Time horizon

I321 Long-term time horizon

I322 Short-term time horizon

O Outcomes

O1 Rural

environment

O11 New residences with limitations

O12 New and suitable residences

O2 Rural income

O21 Significantly increased rural income

O3 Rural vitality

O31 Enhanced rural vitality
The revenue generated from rural renewal, such as the economic income from rural construction land consolidation and redevelopment, is appropriated and distributed among actors.

Various interest claims by different actors have to be dealt with, adjusted and coordinated.

Interest claims from a large number of rural households remain to be settled.

Interest claims from a small number of rural households remain to be settled.

The dimension of time that the decision-makers take into account when appropriating the revenue of rural renewal.

Decision-makers tend to prioritize long-term benefits.

Decision-makers focus on short-term benefits while disregarding long-term benefits.

living The extent to which rural renewal improves the housing and living conditions of a rural area.

Modernized residences are built but fail to fit the context-specific conditions (e.g., living conventions) of a rural area.

Modernized residences fit the context-specific conditions (e.g., living conventions) of a rural area.

The extent to which rural renewal increases income for a rural area.

Rural households greatly benefit from rural renewal, which markedly improves rural wealth.

Whether rural renewal enables a rural area to gain the capability of continuously improving its well-being.

Rural renewal creates job opportunities and/or a reasonable development path (e.g., tourism) for a rural area.

The cases from group 1 (Unsustainable rural renewal) are taken as an example to illustrate how to extract archetypes and sub-archetypes based on the four criteria (see the section Data analysis). The equivalence classes of the cases determined by the FCA (formal concept analysis) are listed below (Table A1.2). 
Table A1.2: Equivalence classes of the cases

\begin{tabular}{|c|c|c|}
\hline No. of equivalence class & Attributes & Cases \\
\hline 1 & A11, GS51, GS61, GS72, I121, I322, O11 & $3,4,12,17,18$ \\
\hline 2 & $\begin{array}{l}\text { R11, A11, GS51, GS54, GS61, GS711, GS72, } \\
\text { I111, I121, I211, I221, I322, O11 }\end{array}$ & $3,4,17,18$ \\
\hline 3 & $\begin{array}{l}\text { A11, GS21, GS51, GS61, GS72, I121, I322, } \\
\text { O11 }\end{array}$ & $3,12,17,18$ \\
\hline 4 & $\begin{array}{l}\text { A11, A32, GS11, GS51, GS61, GS72, I121, } \\
\text { I322, O11 }\end{array}$ & $3,4,12,17$ \\
\hline 5 & $\begin{array}{l}\text { R11, R21, A11, A21, GS51, GS54, GS61, } \\
\text { GS711, GS72, I111, I121, I211, I221, I311, } \\
\text { I322, O11 }\end{array}$ & $3,4,18$ \\
\hline 6 & $\begin{array}{l}\text { R11, A11, GS21, GS51, GS54, GS61, GS711, } \\
\text { GS72, I111, I121, I211, I221, I322, O11 }\end{array}$ & $3,17,18$ \\
\hline 7 & $\begin{array}{l}\text { R11, A11, A32, GS11, GS51, GS54, GS61, } \\
\text { GS711, GS72, I111, I121, I211, I221, I322, O11 }\end{array}$ & $3,4,17$ \\
\hline 8 & $\begin{array}{l}\text { A11, A32, GS11, GS21, GS51, GS61, GS72, } \\
\text { I121, I322, O11 }\end{array}$ & $3,12,17$ \\
\hline 9 & $\begin{array}{l}\text { R11, R21, R22, A11, A21, GS21, GS51, GS54, } \\
\text { GS61, GS711, GS72, I111, I121, I211, I221, } \\
\text { I311, I322, O11 }\end{array}$ & 3,18 \\
\hline 10 & $\begin{array}{l}\text { R11, R21, A11, A21, A32, GS11, GS42, GS51, } \\
\text { GS54, GS61, GS711, GS72, I111, I121, I211, } \\
\text { I221, I311, I322, O11 }\end{array}$ & 3,4 \\
\hline 11 & $\begin{array}{l}\text { R11, A11, A32, GS11, GS21, GS51, GS54, } \\
\text { GS61, GS711, GS72, I111, I121, I211, I221, } \\
\text { I322, O11 }\end{array}$ & 3,17 \\
\hline 12 & $\begin{array}{l}\text { A11, A32, GS11, GS21, GS31, GS51, GS61, } \\
\text { GS72, I121, I322, O11 }\end{array}$ & 3,12 \\
\hline 13 & $\begin{array}{l}\text { A11, A22, A32, GS11, GS21, GS41, GS51, } \\
\text { GS61, GS72, I121, I312, I322, O11 }\end{array}$ & 12,17 \\
\hline 14 & $\begin{array}{l}\text { R11, R21, R22, A11, A13, A21, GS12, GS21, } \\
\text { GS51, GS53, GS54, GS61, GS63, GS711, } \\
\text { GS72, I111, I121, I211, I221, I311, I322, O11 }\end{array}$ & 18 \\
\hline 15 & $\begin{array}{l}\text { R11, R21, R22, A11, A21, A32, GS11, GS21, } \\
\text { GS31, GS42, GS51, GS54, GS61, GS711, } \\
\text { GS72, I111, I121, I211, I221, I311, I322, O11 }\end{array}$ & 3 \\
\hline 16 & $\begin{array}{l}\text { R11, R31, A11, A22, A32, GS11, GS21, GS32, } \\
\text { GS41, GS51, GS54, GS61, GS711, GS72, I111, } \\
\text { I121, I211, I221, I312, I322, O11 }\end{array}$ & 17 \\
\hline 17 & $\begin{array}{l}\text { R12, A11, A22, A32, GS11, GS21, GS31, } \\
\text { GS41, GS51, GS61, GS712, GS72, I112, I121, } \\
\text { I212, I222, I312, I322, O11 }\end{array}$ & 12 \\
\hline
\end{tabular}


First of all, according to criterion 1, equivalence classes 14-18 are excluded since each of them covers less than two cases. The remaining 13 equivalence classes all meet criterion 2 because the causality between the diagnostic and design attributes and outcome presented by each class can be interpreted by the theory concerning the social-ecological systems (SES) analysis, e.g., new institutional economics. Further, according to criterion 3, equivalence class 1 qualifies as an archetype because it cannot be composed of any other classes. According to criterion 4, equivalence classes 2-4 qualify as sub-archetypes. Equivalence class 2 is composed of the identified archetype (class 1) with six additional attributes, i.e., R11, GS54, GS711, I111, I211 and I221. Equivalence class 3 is composed of the identified archetype (class 1) with one additional attribute, i.e., GS21. Equivalence class 4 is composed of the identified archetype (class 1) with two additional attributes, i.e., A32 and GS11.

However, equivalence classes 5-13 don't qualify as archetypes or sub-archetypes since they fail to meet criterion 3 or 4 . Equivalence class 5 is a sub-archetype of sub-archetype since it is composed of the identified sub-archetype (class 2) with three additional attributes, i.e., R21, A21 and I311. Equivalence class 6 is composed of two identified sub-archetypes, i.e., classes 2 and 3. Equivalence class 7 is composed of two identified sub-archetypes, i.e., classes 2 and 4. Equivalence class 8 is composed of two identified sub-archetypes, i.e., classes 3 and 4 . Equivalence class 9 is composed of two identified sub-archetypes (classes 2 and 3) with four additional attributes, i.e., R21, R22, A21 and I311. Equivalence class 10 is composed of two identified sub-archetypes (classes 2 and 4) with four additional attributes, i.e., R21, A21, GS42 and I311. Equivalence class 11 is composed of three identified sub-archetypes, i.e., classes 2, 3 and 4. Equivalence class 12 is composed of two identified sub-archetypes (classes 3 and 4) with one additional attribute GS31. Equivalence class 13 is composed of two identified sub-archetypes (classes 3 and 4) with three additional attributes A22, GS41 and I312.

Finally, one archetype (class 1) and three sub-archetypes (classes 2-4) are extracted from the cases in the group 1. 


\section{Appendix 2}

Overview of Archetypes and First-hand Cases

\section{Hubei Province}

Case 14: AT3/sAT3.2 Case 15: AT2/sAT2.1, sAT2.2, sAT2.3

Case 16: AT2, AT3/sAT2.2, sAT2.3, sAT3.1 Case 17: AT1/sAT1.1, sAT1.2, sAT1.3

\section{Case 18: AT1/sAT1.2, sAT1.3}

\section{Sichuan Province}

Case 19: AT4/sAT4.1

Case 20: AT5, AT6/sAT5.1,

sAT5.2, sAT6.1, sAT6.2

Case 21: AT4, AT5/sAT4.1, SAT5.1, sAT5.2

Case 22: AT5/sAT5.1

Case 23: AT8/sAT8.2

Case 24: AT7/sAT7.1

Case 25: AT8/sAT8.1

Case 26: AT4/sAT4.1
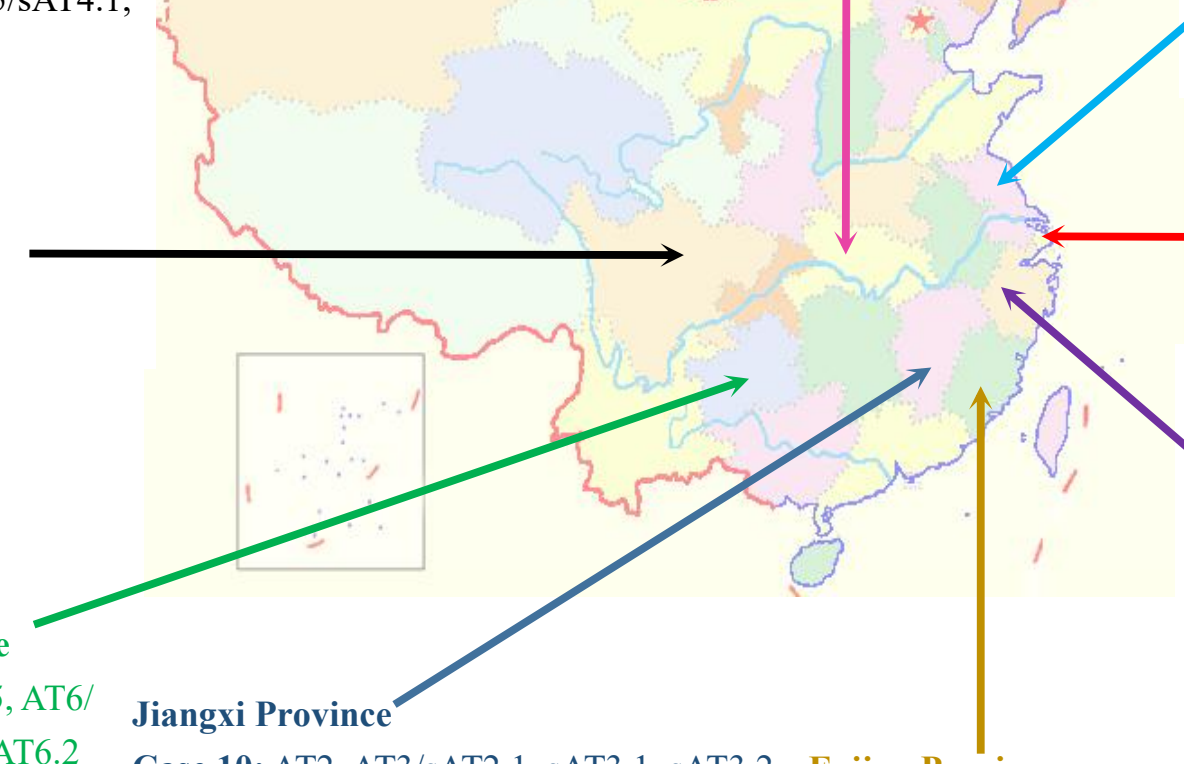

Zhejiang Province

Case 1: AT4, AT5, AT6/sAT4.1, sAT5.2, sAT6.1

Case 2: AT7/sAT7.1, sAT7.2

Case 3: AT1/sAT1.1, sAT1.2, sAT1.3

Guizhou Province
Case 27:AT4, AT5, AT6/ sAT4.1, sAT5.1, sAT6.2

Case 10: AT2, AT3/sAT2.1, sAT3.1, sAT3.2 Fujian Province

Case 4: AT1/sAT1.1, sAT1.2

Case 11: AT2, AT3/sAT2.1, sAT2.3, sAT3.1 Case 6: AT7/sAT7.2

Case 12: AT1/sAT1.1, sAT1.3

Case 7: AT8/sAT8.1

Case 13: AT8/sAT8.1, sAT8.2

Case 8: AT2, AT3/sAT2.1, sAT2.2, sAT3.1, sAT3.2

$\dagger$ More detailed information, e.g., the specific names of the study areas, is concealed for privacy;

AT denotes archetype and sAT denotes sub-archetype.

Fig. A2.1: First-hand cases, regions and archetypes ${ }^{\dagger}$ 


\section{Appendix 3}

Archetypes and Representative Cases

Table A3.1: Archetype 1 Government-led rural renewal with a short-term perspective

\begin{tabular}{ll}
\hline \hline & Case 4 \\
\hline & Residences and other buildings in the village were constructed in the \\
& Mans and 1990s, and they were all in bad or even dangerous condition. \\
& Many residences in the village were underused or not used because an \\
& increasing number of farmers had migrated to urban areas to earn a living \\
& in recent years; however, the county where the village is located \\
& experienced rapid economic development required a large amount of \\
& construction land.
\end{tabular}

2 Process

2.1 Scheme design

Overview

Based on the LUTRG policy ${ }^{\dagger}$
Total cost: 59.04 million yuan, a large amount of investment for the actors Revenue appropriation and distribution (see the details below).
Local government Constructed the detailed scheme and sent it to the upper government level for approval.
Rural households Lacked the right to make decisions.

Scale: 13.29 ha rural construction land and 279 rural households.

2.2 Implementation

Local government Established a top-down administration system that included the leading Afforded all the upfront costs based on the county-level public budget and loans from the local bank. group at the township level and the expertized working group at the village level to implement the rural renewal.

Afforded the costs of constructing new rural residential area by paying for Rural households
2.3 Revenue
appropriation and
distribution

Local government economy.

Fulfilled the LUTRG quotas and thereby relieved the pressure associated with quotas for newly added construction land and boosted the local Earned more than 41.59 million yuan from applying the LUTRG quotas to farmland conversion and urban construction land leasing.

Obtained annual tax income of newly added construction land.

Rural households Obtained new and modernized apartments.

Obtained compensation for relocation, i.e., 68,500 yuan per household.

\section{Outcomes}

Newly built apartments are modernized, and the infrastructure of the new 3.1 Rural living rural residential area is the same as that in the urban residential area. 

site of the village, where the farmland was located.

Certain rural households also complained about the change of living conventions because they found it difficult to acclimate to living in the apartments.

\subsection{Rural income}

$$
-
$$

3.3 Rural vitality

$\dagger$ The policy of Linkage between Urban Land Taking and Rural Land Giving (LUTRG): Rural construction land is re-planned, consolidated and readjusted. A portion of the land is utilized for rural residences in a more intensive way, such as the construction of multi-story buildings. The remainder is restored back to cultivated land and can be traded as the LUTRG quotas. Local governments can obtain the LUTRG quotas from the rural households by the quota trading or the relocation compensation and then authorize extra farmland conversion for urban construction land supply. Other land users may also buy the LUTRG quotas from the rural households and then request an extra amount of agricultural land elsewhere to be supplied to the urban primary land market by the government. And rural households make revenue or get compensation by fulfilling the LUTRG quotas.

Table A3.2: Archetype 2 Small-scale rural renewal with sufficient stakeholder participation

\begin{tabular}{|c|c|}
\hline & Case 15 \\
\hline 1 Background & $\begin{array}{l}\text { The residences in the village were poorly designed and simple. } \\
\text { Rural residential land use in the village was scattered and inefficient. }\end{array}$ \\
\hline \multicolumn{2}{|l|}{2 Process } \\
\hline \multicolumn{2}{|l|}{ 2.1 Scheme design } \\
\hline Overview & $\begin{array}{l}\text { Based on the LUTRG policy. } \\
\text { Scale: } 8.28 \text { ha rural construction land and } 42 \text { rural households. } \\
\text { Total cost: } 5.73 \text { million yuan. } \\
\text { Revenue appropriation and distribution (see the details below). }\end{array}$ \\
\hline Local government & $\begin{array}{l}\text { Made and publicized the draft scheme. } \\
\text { Decided whether take part in the rural renewal or not. }\end{array}$ \\
\hline Rural households & $\begin{array}{l}\text { Discussed the design of new residences as well as the implementation } \\
\text { details, and reached a consensus with the local government. }\end{array}$ \\
\hline \multicolumn{2}{|l|}{ 2.2 Implementation } \\
\hline Rural households & $\begin{array}{l}\text { Afforded all costs but complained that the self-sufficient mode } \\
\text { somewhat increased their finance pressure. } \\
\text { Cooperated with each other without any hold-ups. } \\
\text { Hired a specialized engineering company to restore rural construction } \\
\text { land and construct new rural residences. }\end{array}$ \\
\hline $\begin{array}{lr}2.3 & \text { Revenue } \\
\text { appropriation } & \text { and } \\
\text { distribution } & \end{array}$ & \\
\hline
\end{tabular}

Gained 3.21 million yuan from the LUTRG quota trading. 


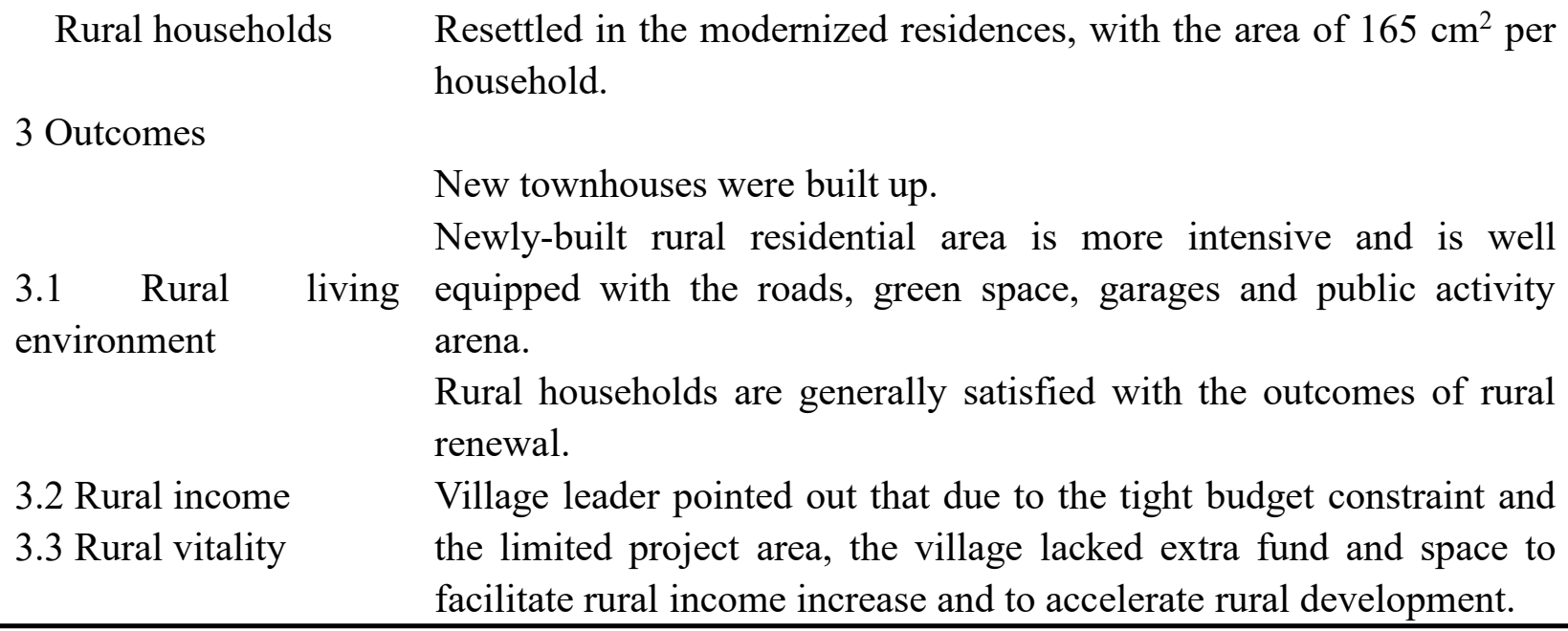

Table A3.3: Archetype 3 Rural renewal with government-village cooperation

ב-Case 14

Case 14

1 Background

The provincial government enacted a policy to encourage village elites, such as entrepreneurs, to organize rural renewal.

Village elite, Mr. Zheng, a successful business man, planned to repay his hometown through improving the rural living conditions.

2 Process

2.1 Scheme design

Based on the LUTRG policy.

Scale: 48.78 ha rural construction land and 308 rural households.

Overview Total cost: approximately 49 million yuan, a large amount and a long duration of investment for the actors.

Revenue appropriation and distribution (see the details below).

Village elite Designed and publicized the scheme.

Rural households Expressed their demands to the village elite.

2.2 Implementation

Village elite

Decided whether take part in the rural renewal or not.

Afforded the major cost, up to 47 million yuan.

Constructed new residences and rural infrastructure.

Afforded and conducted rural construction land restoration.

Supplied the land up to $70 \mathrm{mu}$ for constructing new rural residential

Local government area.

Guaranteed the smooth enforcement of the project by the coercive public power.

Rural households Cooperated with each other and moved out of their old houses in a timely manner.

2.3 Revenue

appropriation and

distribution 
Rural households Obtained modernized apartments with the area of $175 \mathrm{~cm}^{2}$ per household.

Village elite Gained 18.88 million yuan by transferring the LUTRG quotas to the local government.

Obtained the LUTRG quotas for industrialization and urbanization.

Local government Fulfilled the political task of rural renewal assigned by higher-level governments.

3 Outcomes

Sixteen new and modernized 5-storey apartments were built up.

New rural residential area is well planned and equipped with the

3.1 Rural living advanced infrastructure and public service facilities, such as harden environment roads, streetlights, public activity space, green space, supermarkets, restaurants, sewage treatment facilities and security facilities.

3.2 Rural income

Village elite pointed out that given his limited finance capability, he

3.3 Rural vitality was not able to invest in modern agricultural development or rural tourism to further increase rural income and enhance rural vitality.

Table A3.4: Archetype 4 Government participation in large-scale rural renewal with a long-term perspective

\begin{tabular}{ll}
\hline \hline & Case 5 \\
\hline & The provincial government enacted a policy aiming at increasing \\
& rural land use efficiency, constructing new countryside and \\
& facilitating rural-urban integration. \\
& To implement the policy, the local government decided to enforce \\
& rural renewal in the area by making full use of the locational \\
& advantages and the natural resource endowment.
\end{tabular}

2 Process

2.1 Scheme design

Overview

Based on the LUTRG policy.

To develop modern agriculture and rural tourism.

Scale: 53.6 ha rural construction land and 809 rural households.

Total cost: 47.11 million yuan, a large amount of investment for the actors.

Revenue appropriation and distribution (see the details below).

Local government Produced detailed scheme and sent it to the upper government level for approval.

Rural households Claimed their interests concerning new rural residential area as well as agriculture and tourism development to the local government.

2.2 Implementation

Local government

Set up a special fund from the public budget, covering the costs of rural construction land restoration, new residence and infrastructure construction, and agriculture and tourism facilities construction.

Hired a specialized engineering companies to conduct the restoration and construction tasks. 
Rural households

$\begin{array}{lr}2.3 & \text { Revenue } \\ \text { appropriation } & \text { and } \\ \text { distribution } & \end{array}$

Rural households

Local government

\section{Outcomes}

3.1 Rural environment

3.2 Rural income

3.3 Rural vitality
Developed modern agriculture by using the cultivated land restored from the rural construction land and built up a botanical garden relying on the rural agricultural resources.

Cooperated with each other and no hold-ups appeared, given the coercive public power of the government as a guarantee.

Obtained the newly-built and well-equipped townhouses suitable for their living convention.

Obtained sustainable revenue from modern agriculture and rural tourism.

Obtained land use quotas for industrialization and urbanization.

Fulfilled the political task of rural renewal assigned by the higher-level governments.

Rural renewal significantly improved the rural living conditions.

living Restoring and consolidating the idle and extensively-used rural construction land for modern agriculture increased the rural land use efficiency.

Compared with the traditional agriculture, the modern agriculture with high technology is more productive and obviously upgrades on-farm revenue.

Promising rural tourism thereby continuously creates the off-farm revenue.

Development of modern agriculture and rural tourism both increases rural incomes and enhances rural vitality.

Table A3.5: Archetype 5 Self-organized large-scale rural renewal with a long-term perspective

Case 22

Village is situated between the second and third layer of the capital city of the province.

For a long time, the physical condition of the village was inferior.

Rural construction land was utilized in an extensive and scattered form, whereas the village also lacked the space for public activities

1 Background and rural industry development.

The self-governance system in the village was relatively completed and well-functioned. Village congress, the village committee and the supervision committee played the roles of decision-making, executing and monitoring, respectively.

2 Process

2.1 Scheme design 
Overview

Village leaders

Rural households

2.2 Implementation

Village leaders

$\begin{array}{lr}2.3 & \text { Revenue } \\ \text { appropriation } & \text { and } \\ \text { distribution } & \end{array}$

Rural households

3 Outcomes

3.1 Rural living New and modernized townhouses were built up.

environment

3.2 Rural income
Based on the LUTRG policy.

To develop a Chinese chive planting base.

Scale: 32.23 ha rural construction land and 530 rural households.

Total cost: 132.5 million yuan, a large amount of investment for the actors.

Revenue appropriation and distribution (see the details below).

Organized the representatives of farmers to visit the villages successful in rural renewal.

Employed the professional agency to make the scheme, considering the rural households' opinions.

Had access to the relevant information about the scheme and had the right of approval.

Discussed the distribution of the revenue from the quota trading, considering the type, structure and size of the land property of each household.

Afforded all costs.

Employed the engineering company to restore and consolidate the rural construction land.

Built new residences in conformity to the collectively-made building plan.

Actively cooperated with each other and no one withdrew or required additional economic interest.

Organized the so called "Chinese Chive Development Company" to forge a Chinese chive planting base by using the cultivated land restored from the rural construction land, the shareholders of which are the rural households participating the rural renewal.

Gained the quota trading revenue, with about 193,750 yuan per household.

Obtained newly-built townhouses.

Obtained the "Double 350" bonus, that is, a shareholder can get 350 $\mathrm{kg}$ Chinese chive twice a year, which can be converted to cash against the instant market price.

Received annual dividends.

The infrastructure and public facilities, such as roads, water pumps, lights, green area and public space, were all renewed.

Rural income is surely improved because of the "Double 350" bonus and the annual dividends. 
The existence of Chinese Chive Development Company facilitated the local agricultural production shifting from the disperse and small-scale one to a consolidated and large-scale one, which contributed to the rural industry transformation and upgrade.

Table A3.6: Archetype 6 Enterprise participation in large-scale rural renewal with a long-term perspective

\begin{tabular}{ll}
\hline \hline & Case 9 \\
\hline & The case area is located at the traffic hub of the Yangtze River Delta, \\
& connecting Zhejiang Province and Shanghai City. \\
& The local government planned to transform the area into a modern \\
& agriculture base and a new tourism spot in cooperation with \\
& enterprises.
\end{tabular}

2 Process

2.1 Scheme design

Overview

Local government

Rural households

Enterprises

2.2 Implementation

Local government

Rural households

Enterprises
To restore or consolidate the extant and idle rural construction land for modern agricultural use and new residence construction and tourism use, respectively

Scale: 1771.22 ha rural construction land and 599 rural households Total cost: more than 600 million yuan, a large amount of investment for the actors.

Revenue appropriation and distribution (see the details below).

Made and publicized the draft scheme.

Considered the stakeholders' opinions carefully and adjusted the scheme.

Proposed their demands for the new rural residential area and the rural industrial development.

Decided whether participate in the rural renewal or not.

Claimed their own interests in the rural tourism development.

Afforded the major cost from the public budget, approximately 420 million yuan, including the relocation compensation, the rural construction land restoration and the agriculture facilities construction.

Hired a specialized engineering companies to conduct the restoration and construction tasks.

Afforded the costs of constructing new rural residential area by paying for their new residences, i.e., 300,000 yuan per household.

Moved out of the old houses in a timely manner.

Established a company for modern agriculture development.

Invested in the tourism facilities construction.

Developed rural tourism, such as building hotels, restaurants and shops. 


$\begin{array}{lr}2.3 & \text { Revenue } \\ \text { appropriation } & \text { and } \\ \text { distribution } & \end{array}$

Rural households Obtained compensation for relocation, i.e., 500,000 yuan per household.

Gained the annual dividends from the agricultural company.

Obtained off-farm jobs created by the rural tourism development.

Local government Upgraded both the political and economic performance in the rural renewal.

Built up two village hotels, six village restaurants and four village

Enterprises specialty shops.

Gained sustainable revenue from the rural tourism.

3 Outcomes

3.1 Rural living modernized, and the infrastructure is well-equipped.

environment Rural households nowadays share the same level of living quality as the urban inhabitants.

3.2 Rural income Rural renewal also continuously increases rural income, such as the annual dividends from the modern agriculture development and the off-farm revenue from the tourism development.

3.3 Rural vitality Rural industrial development both in agriculture and tourism enhances the rural vitality.

Table A3.7: Archetype 7 Government participation in rural renewal with a large number of rural households involved and a long-term perspective

\section{Case 6}

Many residences in the village were simple and the living conditions had to be improved.

Several village elites, also the entrepreneurs, were willing to promote

1 Background the improvement of living conditions with the purpose of repaying their homeland.

The local government planned to set up a model for rural renewal to meet the requirement from the higher-level governments.

2 Process

2.1 Scheme design

To re-plan and consolidate the rural construction land for new and intensive residences and rural industrialization.

Overview Scale: 2 ha rural construction land and 415 rural households.

Total cost: 70 million yuan, a large amount of investment for the actors.

Revenue appropriation and distribution (see the details below). 
Local government

Rural households

2.2 Implementation

Local government

Village elites

Rural households

$\begin{array}{lr}2.3 & \text { Revenue } \\ \text { appropriation } & \text { and } \\ \text { distribution } & \end{array}$

\section{Outcomes}

Rural households

Local government

$3.1 \quad$ Rural living
environment

3.2 Rural income

3.3 Rural vitality
Produced the draft scheme with the assistance from the specialized engineering institute, and then publicized it.

Incorporated the rural households' opinions into the scheme or made the responses to the rural households.

Expressed their opinions on the scheme.

Decided whether to participated in rural renewal or not.

Provided the funds in the various forms, including the subsidy of new countryside construction, the budget of pilot project and the reward of beautiful country.

Served as an external guarantee for the smooth enforcement of the project, relying on the coercive public power.

Afforded the major costs, up to 60 million yuan.

Consolidated the rural construction land and constructed the new residences.

Accumulated a considerable amount of social capital to generate cooperation and reciprocity.

Solved potential conflicts and facilitated cooperation through the village council.

Obtained new townhouses in the modernized residential area.

Gained the annual dividends since the village committee rented out the rural industrial land that was generated from the rural construction land consolidation and intensive use.

Partially achieved the political task assigned by the higher-level governments because this village became a model and successful experience for rural renewal in the local area.

New townhouses were built up.

Rural infrastructure, containing water, electricity, sewage system, etc., was upgraded.

Rural households share the same level of living quality with the urban inhabitants.

Rural industrialization not only produces the land rent for the village, but also creates the off-farm jobs for the rural households.

Rural renewal also provided the space, namely, the rural industrial land, for the rural industrial development.

Table A3.8: Archetype 8 Self-organized small-scale rural renewal with a long-term perspective 
Village is in proximity to a stream and its landscape and ecology are of high quality, which attracts an increasing number of urban citizens to the village for vacations.

1 Background

2 Process

2.1 Scheme design

Overview

Village elite

Rural households

2.2 Implementation Village elite

Rural households

2.3 Revenue appropriation and distribution
The infrastructure and living conditions were inferior for a long time. A village elite named $\mathrm{Wu}$, also an entrepreneur, intended to construct a village hotel to develop rural tourism in the village with the purpose of repaying his homeland.

As a model for farmer autonomy, the village has established a completed coordination mechanism that includes proposals, discussions, decision-making and enforcement during the long period of farmer autonomy.

To re-plan and readjust the rural construction land; to relocate the rural households with a small proportion of readjusted land; to construct a village hotel to develop rural tourism.

Scale: 2.22 ha rural construction land and 37 rural households.

Total cost: 31.19 million yuan.

Revenue appropriation and distribution (see the details below).

Designed the scheme, considering the rural households' opinions.

Had access to the detailed information about the scheme.

Pooled together all their land assets, including the old houses and rural construction land to generate a bundled price for the negotiation with the village elite, through the collective discussion.

Discussed the distribution of the revenue from the rural land transfer, considering the type, structure and size of the land property of each household.

Had the right to decide whether to participate in rural renewal depending on the outcome of negotiation.

Afforded all costs.

Consolidated the rural construction land and constructed a village hotel and rural infrastructure.

Constructed the new residences with a small part of rural construction land according to the plan that was collectively made.

Transferred the remainder of the rural construction land to the village elite for the village hotel construction.

Actively cooperated and no one withdrew or required additional economic interest, i.e., asked for higher compensation or more land for relocation. 
Obtained revenue from the rural construction land transfer, with more

Rural households than 100,000 yuan per household.

Obtained new townhouses.

Obtained off-farm jobs created by the rural tourism development.

Village elite Obtained continuous revenue from the operation of the village hotel.

\section{Outcomes}

Old and damaged houses were replaced by the newly constructed 3.1 Rural living townhouses.

environment The infrastructure and public facilities, such as roads, water pumps, lights and green open space, were also improved.

3.2 Rural income More than 120 farmers (the total number of farmers in the village is 304) are employed by the village hotel, which increases the rural households' income.

3.3 Rural vitality The development of rural tourism gradually promotes the transformation of industry from agriculture to non-agriculture.

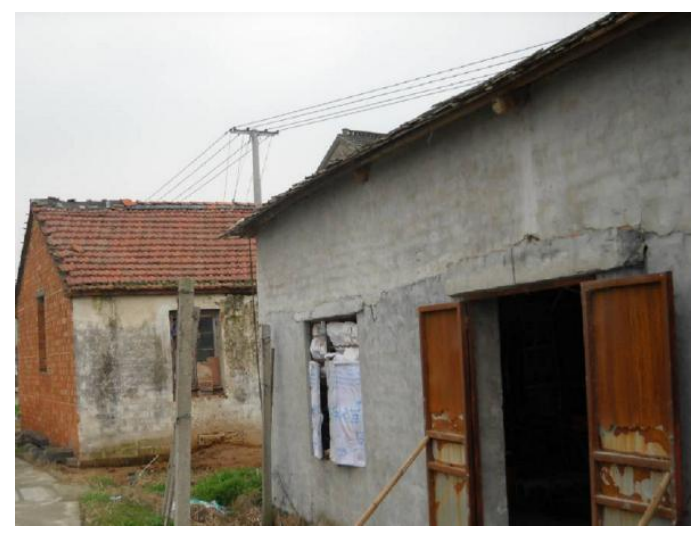

Panel I. Old residences in Case 4

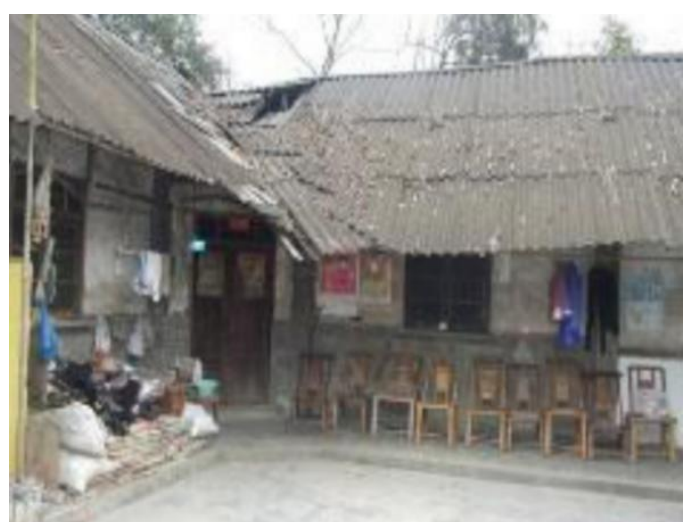

Panel II. Old residences in Case 22

Fig. A3.1: Rural living environments before rural renewal

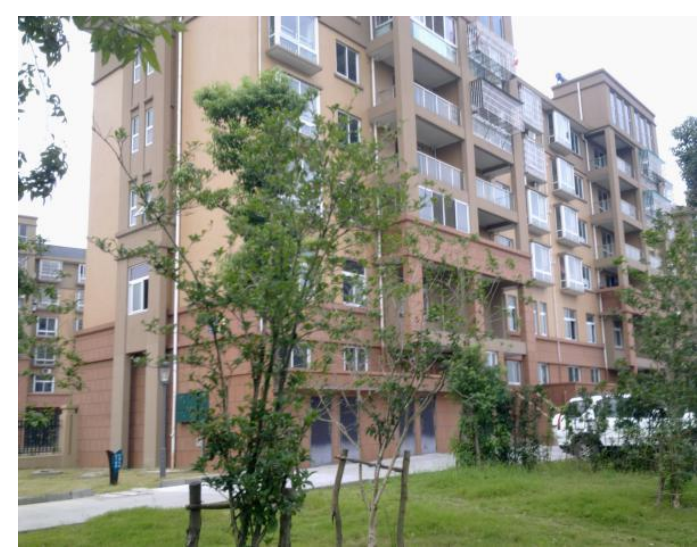

Panel I. New residences in Case 4

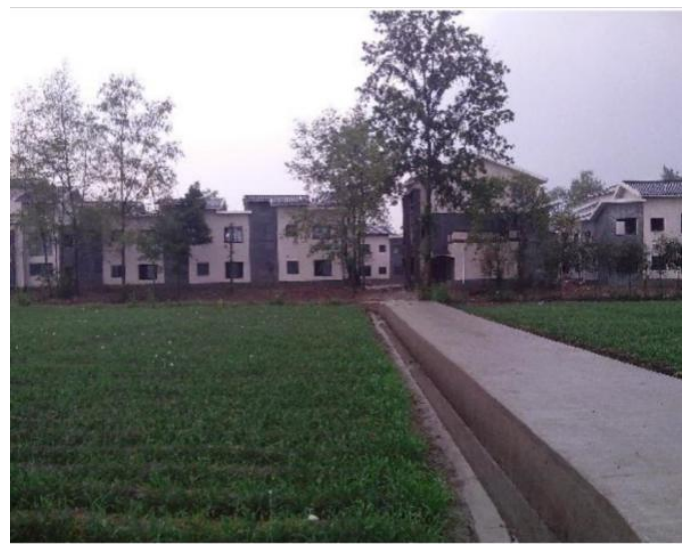

Panel II. New residences in Case 22

Fig. A3.2: Rural living environments after rural renewal 


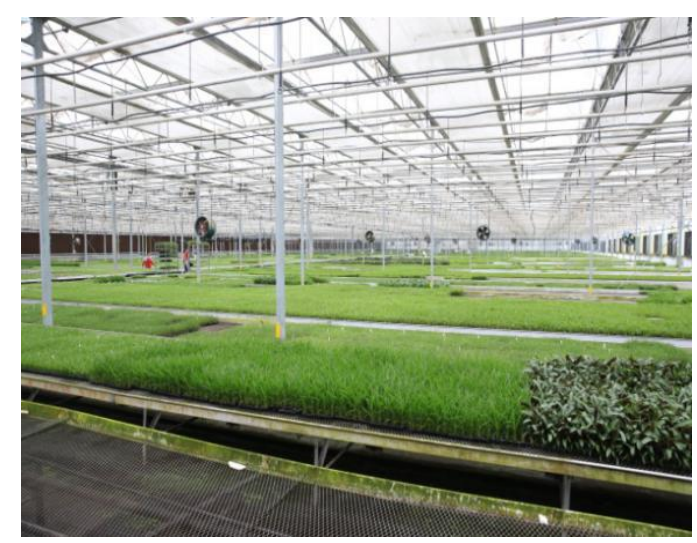

Panel I. Modern agriculture in Case 9

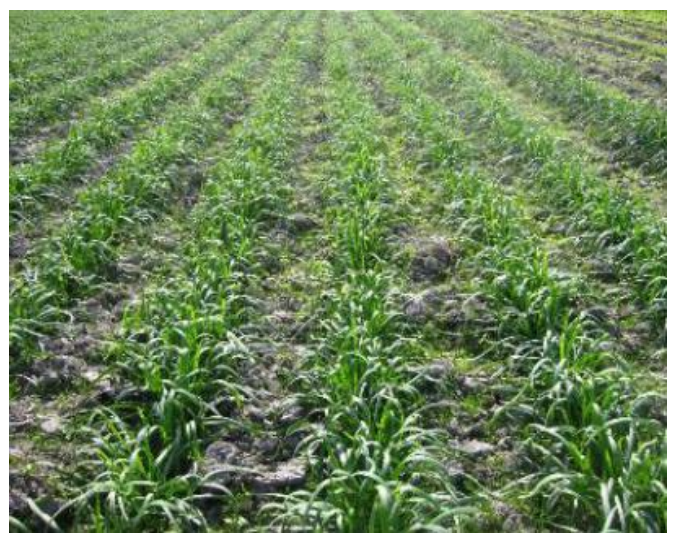

Panel II. Chinese chive planting base in Case 22

Fig. A3.3: Rural income and vitality: facilitating agricultural development

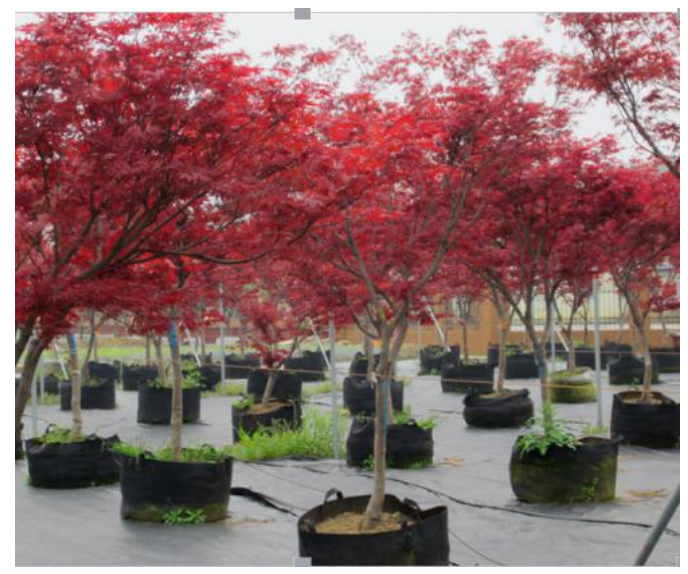

Panel I. Botanical garden in Case 5

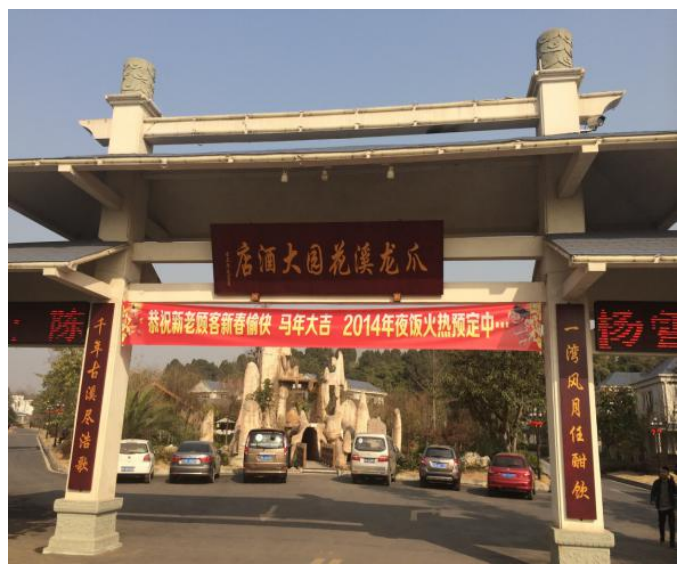

Panel II. Village hotel in Case 25

Fig. A3.4: Rural income and vitality: facilitating rural tourism 